\title{
Possibilidade de antecipação do parto por anencefalia
}

\section{Arguição de Descumprimento de Preceito Fundamental 54 Distrito Federal}

Supremo Tribunal Federal (STF)

VOTO

O SENHOR MINISTRO MARCO AURÉLIO (RELATOR) - Padre Antônio Vieira disse-nos: "E como o tempo não tem, nem pode ter consistência alguma, e todas as coisas desde o seu princípio nasceram juntas com o tempo, por isso nem ele, nem elas podem parar um momento, mas com perpétuo moto, e resolução insuperável passar, e ir passando sempre" - Sermão da Primeira Dominga do Advento.

A questão posta nesta ação de descumprimento de preceito fundamental revela-se uma das mais importantes analisadas pelo Tribunal. É inevitável que o debate suscite elevada intensidade argumentativa das partes abrangidas, do Poder Judiciário e da sociedade. Com o intuito de corroborar a relevância do tema, faço menção a dois dados substanciais. Primeiro, até o ano de 2005, os juízes e tribunais de justiça formalizaram cerca de 3 mil autorizações para a interrupção gestacional em razão da incompatibilidade do feto com a vida extrauterina, o que demonstra a necessidade de pronunciamento por parte deste Tribunal. Segundo, o Brasil é o quarto país no mundo em casos de fetos anencéfalos. Fica atrás do Chile, México e Paraguai. A incidência é de aproximadamente um a cada mil nascimentos, segundo dados da Organização Mundial de Saúde, confirmados na audiência pública. Chega-se a falar que, a 
cada três horas, realiza-se o parto de um feto portador de anencefalia. Esses dados foram os obtidos e datam do período de 1993 a 1998, não existindo notícia de realização de nova sondagem.

Para não haver dúvida, faz-se imprescindível que se delimite o objeto sob exame. Na inicial, pede-se a declaração de inconstitucionalidade, com eficácia para todos e efeito vinculante, da interpretação dos artigos 124, 126 e 128, incisos I e II, do Código Penal ${ }^{1}$ (Decreto-Lei no 2.848/40) que impeça a antecipação terapêutica do parto na hipótese de gravidez de feto anencéfalo, previamente diagnosticada por profissional habilitado. Pretende-se o reconhecimento do direito da gestante de submeter-se ao citado procedimento sem estar compelida a apresentar autorização judicial ou qualquer outra forma de permissão do Estado.

Destaco a alusão feita pela própria arguente ao fato de não se postular a proclamação de inconstitucionalidade abstrata dos tipos penais, o que os retiraria do sistema jurídico. Busca-se tão somente que os referidos enunciados sejam interpretados conforme a Constituição. Dessa maneira, mostra-se inteiramente despropositado veicular que o Supremo examinará, neste caso, a descriminalização do aborto, especialmente porque, consoante se observará, existe distinção entre aborto e antecipação terapêutica do parto. Apesar de alguns autores utilizarem expressões "aborto eugênico ou eugenésico" ou "antecipação eugênica da gestação", afasto-as, considerado o indiscutível viés ideológico e político impregnado na palavra eugenia.

Inescapável é o confronto entre, de um lado, os interesses legítimos da mulher em ver respeitada sua dignidade e, de outro, os interesses de parte da sociedade que deseja proteger todos os que a integram - sejam os que nasceram, sejam os que estejam para nascer - independentemente da

\footnotetext{
${ }^{1}$ Aborto provocado pela gestante ou com seu consentimento

Art. 124 - Provocar aborto em si mesma ou consentir que outrem lho provoque:

Pena - detenção, de um a três anos.

Aborto provocado por terceiro

Art. 126 - Provocar aborto com o consentimento da gestante:

Pena - reclusão, de um a quatro anos.

Parágrafo único. Aplica-se a pena do artigo anterior, se a gestante não é maior de quatorze anos, ou é alienada ou débil mental, ou se o consentimento é obtido mediante fraude, grave ameaça ou violência.

Art. 128 - Não se pune o aborto praticado por médico:

Aborto necessário

I - se não há outro meio de salvar a vida da gestante;

Aborto no caso de gravidez resultante de estupro

II - se a gravidez resulta de estupro e o aborto é precedido de consentimento da gestante ou, quando incapaz, de seu representante legal.
} 
condição física ou viabilidade de sobrevivência. $\mathrm{O}$ tema envolve a dignidade humana, o usufruto da vida, a liberdade, a autodeterminação, a saúde e o reconhecimento pleno de direitos individuais, especificamente, os direitos sexuais e reprodutivos de milhares de mulheres. No caso, não há colisão real entre direitos fundamentais, apenas conflito aparente.

Na discussão mais ampla sobre o aborto, consoante salientam Telma Birchal e Lincoln Farias, incumbe identificar se existe algum motivo que autorize a interrupção da gravidez de um feto sadio. No debate sobre a antecipação terapêutica do parto de feto anencéfalo, o enfoque mostra-se diverso. Cabe perquirir se há justificativa para a lei compelir a mulher a manter a gestação, quando ausente expectativa de vida para o feto. ${ }^{2}$ Conforme Luís Carlos Martins Alves Júnior, cumpre indagar se a mulher que se submete à antecipação terapêutica do parto de feto anencéfalo deve ser presa e ainda se a possibilidade de prisão reduziria a realização dos procedimentos médicos ora em discussão. ${ }^{3}$

Senhor presidente, na verdade, a questão posta sob julgamento é única: saber se a tipificação penal da interrupção da gravidez de feto anencéfalo coaduna-se com a Constituição, notadamente com os preceitos que garantem o Estado laico, a dignidade da pessoa humana, o direito à vida e a proteção da autonomia, da liberdade, da privacidade e da saúde. Para mim, Senhor Presidente, a resposta é desenganadamente negativa. Comecemos pelo Estado laico.

\section{A República Federativa do Brasil como Estado laico}

"Dai a César o que é de César e a Deus o que é de Deus" Evangelho de São Marcos, capítulo XII, versículos 13 a 17.

Nas palavras de De Plácido e Silva: “LAICO. Do latim laicus, é o mesmo que leigo, equivalendo ao sentido de secular, em oposição ao de bispo, ou religioso".4

\footnotetext{
${ }^{2}$ Aborto de fetos anencéfalos. Ethic@. Revista Internacional de Filosofia da Moral, Florianópolis, v. 8, n. 1, p. 19-30, jun. 2009.

${ }^{3}$ In: O direito fundamental do feto anencefálico. Uma análise do processo e julgamento da Arguição de Descumprimento de Preceito Fundamental no 54. Jus Navigandi, Teresina, ano 11, n. 1.555, 4 out. 2007. Disponível em: <http://jus2.uol.com.Br/doutrina/texto.asp?id=10488>.

${ }^{4}$ SILVA, De Plácido. Vocabulário jurídico conciso. Editora Forense Jurídica. 1. ed., 2008. p. 45. Anoto não estar em discussão eventual distinção terminológica entre laicidade e laicismo.
} 
A Constituição do Império, de 25 de março de 1824, inicia-se com "EM NOME DA SANTÍSSIMA TRINDADE" e, no artigo 5, preconiza que "A Religião Catholica Apostólica Romana continuará a ser a Religião do Império. Todas as outras Religiões serão permitidas com seu culto doméstico, ou particular em casas para isso destinadas, sem fórma alguma exterior do Templo" (grifei).

José Afonso da Silva, ao comentá-la, assevera: ${ }^{5}$

... realmente, a Constituição Política do Império estabelecia que a Religião Católica Apostólica Romana era a Religião do Império (art. $5^{\circ}$ ) , com todas as consequências derivantes dessa qualidade de Estado confessional, tais como a de que as demais religiões seriam simplesmente toleradas, a de que o Imperador, antes de ser aclamado, teria que jurar manter aquela religião (art. 103), a de que competia ao Poder Executivo nomear os bispos e prover os benefícios eclesiásticos (art. 102, II), bem como conceder ou negar os beneplácitos a atos da Santa Sé (art. 102, XIV), quer dizer, tais atos só teriam vigor e eficácia no Brasil se obtivessem aprovação do governo brasileiro.

Apesar do disposto no artigo 5ํㅡ, o artigo 179 da Constituição do Império assegurava a "inviolabilidade dos direitos civis e políticos dos cidadãos brasileiros, que tem por base a liberdade, a segurança civil individual e a propriedade". Da leitura dos incisos, verifica-se a liberdade de ação em geral, ainda que simplesmente formal. ${ }^{6}$

\footnotetext{
${ }^{5}$ SILVA, José Afonso da. Curso de direito constitucional positivo. 22. ed. São Paulo: Malheiros, 2003. p. 249-250.

${ }^{6}$ Art. 179.

I. Nenhum Cidadão póde ser obrigado a fazer, ou deixar de fazer alguma cousa, senão em virtude da Lei.

II. Nenhuma Lei será estabelecida sem utilidade publica.

III. A sua disposição não terá effeito retroactivo.

IV. Todos podem communicar os seus pensamentos, por palavras, escriptos, e publical-os pela Imprensa, sem dependencia de censura; com tanto que hajam de responder pelos abusos, que commetterem no exercicio deste Direito, nos casos, e pela fórma, que a Lei determinar.

V. Ninguem póde ser perseguido por motivo de Religião, uma vez que respeite a do Estado, e não offenda a Moral Publica. (...)

XXIV. Nenhum genero de trabalho, de cultura, industria, ou commercio póde ser prohibido, uma vez que não se opponha aos costumes publicos, á segurança, e saude dos Cidadãos.

XXXIV. Os Poderes Constitucionaes não podem suspender a Constituição, no que diz respeito aos direitos individuaes, salvo nos casos, e circumstancias especificadas no paragrapho seguinte.
} 
Elza Galdino relembra que o Decreto $n^{\underline{0}}$ 001144, de 11 de setembro de 1861, indicava a natureza tolerante do Império brasileiro. Transcrevo-o: ${ }^{7}$

Faz extensivos os efeitos civis dos nascimentos, celebrados na forma das leis do Império, aos das pessoas que professarem religião diferente da do Estado, e determina que sejam regulados o registro e provas destes casamentos e dos nascimentos e óbitos das ditas pessoas bem como as condições necessárias para que os pastores de religiões toleradas possam praticar atos que produzam efeitos civis.

Antes de ser aclamado, cabia ao imperador realizar o juramento de manter a religião católica como oficial e nacional, devidamente protegida, nos seguintes termos:

Juro manter a religião católica apostólica romana, a integridade, a indivisibilidade do Império, observar e fazer observar a Constituição Política da nação brasileira e mais leis do Império e prover ao bem geral do Brasil, quanto em mim couber (artigo 103 do Texto Maior de 1824).

Era tamanha a importância atribuída ao referido juramento que, na dicção da Lei Fundamental de 15 de outubro de 1827, seriam severamente punidos todos aqueles que contribuíssem para a sua destruição. Caso se tratasse de ministros e secretários de Estado, sobre eles recairia a acusação de traição. ${ }^{8}$

Pode-se afirmar que, até então, o Brasil era um Estado religioso relativamente tolerante. Relativamente porque, embora estendesse os efeitos civis a atos religiosos em geral e permitisse a realização de cultos não católicos,

\footnotetext{
XXXV. Nos casos de rebellião, ou invasão de inimigos, pedindo a segurança do Estado, que se dispensem por tempo determinado algumas das formalidades, que garantem a liberdade individual, poder-se-ha fazer por acto especial do Poder Legislativo. Não se achando porém a esse tempo reunida a Assembléa, e correndo a Patria perigo imminente, poderá o Governo exercer esta mesma providencia, como medida provisoria, e indispensavel, suspendendo-a immediatamente que cesse a necessidade urgente, que a motivou; devendo num, e outro caso remetter á Assembléa, logo que reunida fôr, uma relação motivada das prisões, e d'outras medidas de prevenção tomadas; e quaesquer Autoridades, que tiverem mandado proceder a ellas, serão responsaveis pelos abusos, que tiverem praticado a esse respeito.

${ }^{7}$ Estado sem Deus - A obrigação da laicidade na Constituição. Belo Horizonte: Del Rey, 2006. p. 71.

${ }^{8}$ SCAMPINI, José. A liberdade religiosa nas Constituições brasileiras (estudo filosófico-jurídico comparado). Revista de Informação Legislativa, v. 11, n. 41, p. 75-126, jan./mar. 1974. p. 81.
} 
limitava-os ao âmbito doméstico e aos templos, proibindo qualquer manifestação não católica exterior.

No limiar da transição do Império para a República, o Estado brasileiro houve por bem separar-se da Igreja, conforme evidencia a ementa do Decreto no 119-A, de 7 de janeiro de 1890, o qual:

Proíbe a intervenção da autoridade federal e dos Estados federados em matéria religiosa, consagra a plena liberdade de cultos, extingue o padroado e estabelece outras providências.

Registro histórico interessante é a correspondência entre dom Marcelo Costa, bispo do Pará, e Ruy Barbosa, ministro do Governo Provisório incumbido de redigir o decreto do qual adviria a separação entre o Estado e a Igreja. Em 22 de dezembro de 1889, dom Marcelo Costa, impossibilitado de comparecer a certa reunião, enviou carta ao ministro manifestando-se acerca do "decreto de separação":

Não desejo a separação, não dou um passo, não faço um aceno para que se decrete no Brasil o divórcio entre o Estado e a Igreja. Tal decreto alterando profundamente a situação da Igreja poderia causar grande abalo no país. Talvez fosse de melhor prudência, de melhor política e até mais curial reservar esse assunto para a próxima assembleia constituinte. Mas, se o Governo Provisório está decidido a promulgar o decreto, atenda-se o mais possível à situação da Igreja, adquirida entre nós, há cerca de três séculos. É evidente que sob o pretexto de liberdade religiosa não devemos ser esbulhados. ${ }^{9}$

A laicidade, que não se confunde com laicismo, ${ }^{10}$ foi finalmente alçada a princípio constitucional pela Constituição da República dos Estados Unidos do Brasil, de 24 de fevereiro de 1891, cujo artigo 11, § $2^{\circ}$, dispôs ser vedado aos Estados e à União "estabelecer, subvencionar ou embaraçar o exercício de cultos religiosos". Desde então, todos os textos constitucionais reproduziram

\footnotetext{
${ }^{9}$ Apud Scampini, ob. cit. p. 81.

${ }_{10}$ MACHADO, Jónatas Eduardo Mendes. Liberdade religiosa numa comunidade constitucional inclusiva. Coimbra Editora, 1996. p. 306 e 307. Laicidade significa uma atitude de neutralidade do Estado, ao passo que laicismo designa uma atitude hostil do Estado para com a religião.
} 
o conteúdo desse artigo - a Constituição de 1934 fê-lo no artigo 17, incisos II e III, ${ }^{11}$ ampliando a proibição aos entes municipais; o Texto Maior de 1937 menciona-o no artigo 32, alínea " $\mathrm{b}^{\text {"; } ; 12}$ a Carta de 1946 dispôs a respeito do tema no artigo 31, incisos II e III, referindo-se, pela primeira vez, ao Distrito Federal; ${ }^{13}$ no Diploma Constitucional de $1967^{14}$ e na Emenda Constitucional no $1 / 69,{ }^{15}$ o preceito ficou no artigo 9o, inciso II.

Na mesma linha, andou o constituinte de 1988, que, sensível à importância do tema, dedicou-lhe os artigos 5o, inciso VI, e 19, inciso I, embora, àquela altura, já estivesse arraigada na tradição brasileira a separação entre Igreja e Estado. Nos debates havidos na Assembleia Nacional Constituinte, o presidente da Comissão da Soberania e dos Direitos e Garantias do Homem e da Mulher, Antônio Mariz, enfatizou: "o fato de a separação entre Igreja e Estado estar hoje incorporada aos valores comuns à nacionalidade, não é suficiente para eliminar do texto constitucional o princípio que a expressa".

Nesse contexto, a Constituição de 1988 consagra não apenas a liberdade religiosa - inciso VI do artigo $5^{\circ}$ - , como também o caráter laico do Estado - inciso I do artigo 19. Citados preceitos estabelecem:

Art. 5 - Todos são iguais perante a lei, sem distinção de qualquer natureza, garantindo-se aos brasileiros e aos estrangeiros residentes no País a inviolabilidade do direito à vida, à liberdade, à igualdade, à segurança e à propriedade, nos termos seguintes:

\footnotetext{
${ }^{11}$ Art 17 - É vedado à União, aos Estados, ao Distrito Federal e aos Municípios:

II - estabelecer, subvencionar ou embaraçar o exercício de cultos religiosos;

III - ter relação de aliança ou dependência com qualquer culto, ou igreja sem prejuízo da colaboração recíproca em prol do interesse coletivo;

12 Art 32 - É vedado à União, aos Estados e aos Municípios: b) estabelecer, subvencionar ou embaraçar o exercício de cultos religiosos;

${ }^{13}$ Art 31 - À União, aos Estados, ao Distrito Federal e aos Municípios é vedado: II - estabelecer ou subvencionar cultos religiosos, ou embaraçar-lhes o exercício; III - ter relação de aliança ou dependência com qualquer culto ou igreja, sem prejuízo da colaboração recíproca em prol do interesse coletivo;

${ }^{14}$ Art $9^{\circ}-$ À União, aos Estados, ao Distrito Federal e aos Municípios é vedado: II - estabelecer cultos religiosos ou igrejas; subvencioná-los; embaraçar-lhes o exercício; ou manter com eles ou seus representantes relações de dependência ou aliança, ressalvada a colaboração de interesse público, notadamente nos setores educacional, assistencial e hospitalar;

${ }^{15}$ Art. 9o - À União, aos Estados, ao Distrito Federal, aos Territórios e aos Municípios é vedado: (Redação dada pela Emenda Constitucional no 16, de 1980) II - estabelecer cultos religiosos ou igrejas, subvencioná-los, embaraçar-lhes o exercício ou manter com êles ou seus representantes relações de dependência ou aliança, ressalvada a colaboração de interêsse público, na forma e nos limites da lei federal, notadamente no setor educacional, no assistencial e no hospitalar; e
} 
VI - é inviolável a liberdade de consciência e de crença, sendo assegurado o livre exercício dos cultos religiosos e garantida, na forma da lei, a proteção aos locais de culto e a suas liturgias;

(...)

Art. 19. É vedado à União, aos Estados, ao Distrito Federal e aos Municípios:

I - estabelecer cultos religiosos ou igrejas, subvencioná-los, embaraçarlhes o funcionamento ou manter com eles ou seus representantes relações de dependência ou aliança, ressalvada, na forma da lei, a colaboração de interesse público;

(...)

Pois bem, senhor presidente, não obstante tais dispositivos, o preâmbulo da atual Carta alude expressamente à religião cristã. Eis o teor:

Nós, representantes do povo brasileiro, reunidos em Assembleia Nacional Constituinte para instituir um Estado Democrático, destinado a assegurar o exercício dos direitos sociais e individuais, a liberdade, a segurança, o bem-estar, o desenvolvimento, a igualdade e a justiça como valores supremos de uma sociedade fraterna, pluralista e sem preconceitos, fundada na harmonia social e comprometida, na ordem interna e internacional, com a solução pacífica das controvérsias, promulgamos, sob a proteção de Deus, a seguinte CONSTITUIÇÃO DA REPÚBLICA FEDERATIVA DO BRASIL.

No entender de Pinto Ferreira, “(...) o preâmbulo é parte integrante da Constituição e tem a sua significação política, como uma reprodução altamente clara do conteúdo da Constituição em forma popular". ${ }^{16}$ Antes, João Barbalho anotara não ser o preâmbulo “(...) uma peça inútil ou de mero ornato na construção dela [Constituição]; as simples palavras que o constituem resumem e proclamam o pensamento primordial e os intuitos dos que a arquitetaram". ${ }^{17}$

\footnotetext{
${ }^{16}$ Comentários à Constituição Brasileira. São Paulo: Saraiva, 1989. v. 1, p. 71.

${ }^{17}$ CAVALCANTI, João Barbalho Uchoa. Constituição Federal Brasileira: comentários. Brasília: Senado Federal, 1992.
} 
A despeito de tais opiniões, essa não foi a posição abraçada por este Supremo quando do julgamento da Ação Direta de Inconstitucionalidade $\mathrm{n}^{\mathrm{o}}$ 2.076/AC, da relatoria do ministro Carlos Velloso. ${ }^{18} \mathrm{Na}$ ocasião, o Tribunal explicitou que a menção a Deus carece de força normativa, conforme se depreende da ementa:

CONSTITUCIONAL. CONSTITUIÇÃO: PREÂMBULO. NORMAS CENTRAIS. Constituição do Acre. I. - Normas centrais da Constituição Federal: essas normas são de reprodução obrigatória na Constituição do Estado-membro, mesmo porque, reproduzidas, ou não, incidirão sobre a ordem local. Reclamações 370-MT e 383-SP (RTJ 147/404). II. Preâmbulo da Constituição: não constitui norma central. Invocação da proteção de Deus: não se trata de norma de reprodução obrigatória na Constituição estadual, não tendo força normativa. III. - Ação direta de inconstitucionalidade julgada improcedente.

Naquela assentada, o eminente ministro Sepúlveda Pertence asseverou que a "locução 'sob a proteção de Deus' não é norma jurídica, até porque não se teria a pretensão de criar obrigações para a divindade invocada. Ela é uma afirmação de fato jactanciosa e pretensiosa, talvez - de que a divindade estivesse preocupada com a Constituição do país" ${ }^{19}$

Conclui-se que, a despeito do preâmbulo, destituído de força normativa - e não poderia ser diferente, especialmente no tocante à proteção divina, a qual jamais poderia ser judicialmente exigida - , o Brasil é um Estado secular tolerante, em razão dos artigos 19, inciso I, e 5o , inciso VI, da Constituição da República. Deuses e césares têm espaços apartados. O Estado não é religioso, tampouco é ateu. O Estado é simplesmente neutro.

Merece observação a temática afeta aos crucifixos e a outros símbolos religiosos nas dependências públicas. A discussão voltou à balha com a recente decisão do Conselho Superior da Magistratura do Estado do Rio Grande do Sul no sentido da retirada dos símbolos religiosos dos espaços públicos dos prédios da Justiça estadual gaúcha. Ao contrário dos tempos imperiais, hoje, reafirmo, a República Federativa do Brasil não é um Estado religioso tolerante

\footnotetext{
${ }^{18}$ Publicado no Diário da Justiça de 8 de agosto de 2003.

${ }^{19}$ José Renato Nalini, em texto publicado na seção Tendências/Debates da Folha de S.Paulo, em 24 de setembro de 2009, sob o título "A cruz e a Justiça", destaca o fato de a nação brasileira ter "nascido" sob a invocação da cruz, já tendo sido chamada, inclusive, de Terra de Santa Cruz.
} 
com minorias religiosas e com ateus, mas um Estado secular tolerante com as religiões, o que o impede de transmitir a mensagem de que apoia ou reprova qualquer delas. ${ }^{20}$

Há mais. Causa perplexidade a expressão "Deus seja louvado" contida nas cédulas de $\mathrm{R} \$ 2,00, \mathrm{R} \$ 5,00, \mathrm{R} \$ 10,00, \mathrm{R}$ \$ 20,00, R\$ 50,00 e R\$ 100,00, inclusive nas notas novas de $\mathrm{R} \$ 50,00$ e R \$ 100,00, essas últimas em circulação a partir de 13 de dezembro de 2010. Em princípio, poder-se-ia cogitar de resquício da colonização portuguesa, quando era comum a emissão de moedas com legendas religiosas, ou de prática advinda do período imperial. Diligência junto ao Banco Central, no entanto, revelou que o Conselho Monetário Nacional - CMN, ao aprovar as características gerais das cédulas de Cruzados e de Cruzeiros, recomendou, de acordo com orientação da Presidência da República, que nelas fosse inscrita a citada locução. Nas cédulas de Cruzados, começou, então, a ser utilizada inclusive naquelas que tiveram a legenda adaptada: Cz\$ 10,00 (Rui Barbosa), Cz\$ 50,00 (Oswaldo Cruz) e Cz\$ 100,00 (Juscelino Kubitschek) - Voto CMN 166/86, Sessão 468, de 26 de junho de 1986. Quando voltou a vigorar o padrão Cruzeiro (1990), foi suprimida no início, inclusive nas que tiveram a legenda adaptada: Cr\$ 100,00 (Cecília Meireles), Cr\$200,00 (República) e Cr\$ 500,00 (Ruschi). Voltou a ser usada a partir da cédula de Cr\$ 50.000,00 (Câmara Cascudo), em 1992, com base no Voto CMN 129/91 - Sessão 525, de 31 de julho de 1991. No início do padrão Real, foi retirada, mas retornou, após a emissão de algumas séries, em observância ao pedido do ministro da Fazenda (Aviso no 395, de 30 de março de 1994, do Ministério da Fazenda, Voto BCB/221, Sessão 1.577, de 8 de junho de 1994, Comunicado MECIR 4.050, de 20 de julho de 1994).

Vê-se, assim, que, olvidada a separação Estado-Igreja, implementou-se algo contrário ao texto constitucional. A toda evidência, o fato discrepa da postura de neutralidade que o Estado deve adotar quanto às questões religiosas. Embora não signifique alusão a uma religião específica, "Deus seja louvado" passa a mensagem clara de que o Estado ao menos apoia um leque de religiões - aquelas que creem na existência de Deus, aliás, um só deus, e o veneram - , o que não se coaduna com a neutralidade que há de ditar os atos estatais, por força dos mencionados artigos 5o, inciso VI, e 19, inciso I, da Constituição da República. Desses dispositivos resulta, entre outras consequências, a proibição de o Estado endossar ou rechaçar qualquer corrente

${ }^{20}$ DWORKIN, Ronald. Is democracy possible here? Princeton University Press, 2006. p. 59. Capítulo 3. Religião e Dignidade. 
confessional. Consigno, para efeito de documentação, que, ao término de 2011, o Ministério Público intercedeu objetivando esclarecimentos sobre a matéria. Porém, não houve, até aqui, desdobramento sob o ângulo da efetiva impugnação.

A laicidade estatal, como bem observa Daniel Sarmento, revela-se princípio que atua de modo dúplice: a um só tempo, salvaguarda as diversas confissões religiosas do risco de intervenção abusiva do Estado nas respectivas questões internas - por exemplo, valores e doutrinas professados, a maneira de cultuá-los, a organização institucional, os processos de tomada de decisões, a forma e o critério de seleção dos sacerdotes e membros - e protege o Estado de influências indevidas provenientes da seara religiosa, de modo a afastar a prejudicial confusão entre o poder secular e democrático - no qual estão investidas as autoridades públicas - e qualquer igreja ou culto, inclusive majoritário. ${ }^{21}$

Analisando o tema sob o primeiro ângulo, que garante a não intervenção estatal no âmbito religioso, este Tribunal, em meados da década de 50, consignou competir exclusivamente à autoridade eclesiástica resolver sobre normas da confissão religiosa. Nas palavras do relator do Recurso Extraordinário no $31.179 / \mathrm{DF}$, ministro Hahnemann Guimarães, então ocupante desta cadeira e professor da Nacional de Direito:

[A] autoridade temporal não pode decidir questão espiritual, surgida entre autoridade eclesiástica e uma associação religiosa. Esta impossibilidade resulta da completa liberdade espiritual, princípio de política republicana, que conduziu à separação entre a Igreja e o Estado, por memorável influência positivista, de que foi órgão Demétrio Ribeiro, com o projeto apresentado ao Governo Provisório em 9 de Dezembro de $1889 .{ }^{22}$

Se, de um lado, a Constituição, ao consagrar a laicidade, impede que o Estado intervenha em assuntos religiosos, seja como árbitro, seja como censor, seja como defensor, de outro, a garantia do Estado laico obsta que dogmas da fé determinem o conteúdo de atos estatais. Vale dizer: concepções morais

\footnotetext{
${ }^{21}$ SARMENTO, Daniel. O crucifixo nos Tribunais e a laicidade do Estado. Revista de Direito do Estado, ano 2, n. 8, p. 75-90, out./dez. 2007.

${ }^{22}$ Diário da Justiça de 26 de junho de 1958.
} 
religiosas, quer unânimes, quer majoritárias, quer minoritárias, não podem guiar as decisões estatais, devendo ficar circunscritas à esfera privada. A crença religiosa e espiritual - ou a ausência dela, o ateísmo - serve precipuamente para ditar a conduta e a vida privada do indivíduo que a possui ou não a possui. Paixões religiosas de toda ordem hão de ser colocadas à parte na condução do Estado. Não podem a fé e as orientações morais dela decorrentes ser impostas a quem quer que seja e por quem quer que seja. Caso contrário, de uma democracia laica com liberdade religiosa não se tratará, ante a ausência de respeito àqueles que não professem o credo inspirador da decisão oficial ou àqueles que um dia desejem rever a posição até então assumida.

No julgamento da Ação Direta de Inconstitucionalidade no 3.510 - na qual se debateu a possibilidade de realização de pesquisas científicas com células-tronco embrionárias - , o Supremo, a uma só voz, primou pela laicidade do Estado sob tal ângulo, assentada em que o decano do Tribunal, ministro Celso de Mello, enfatizou de forma precisa:

nesta República laica, fundada em bases democráticas, o Direito não se submete à religião, e as autoridades incumbidas de aplicá-lo devem despojar-se de pré-compreensões em matéria confessional, em ordem a não fazer repercutir, sobre o processo de poder, quando no exercício de suas funções (qualquer que seja o domínio de sua incidência), as suas próprias convicções religiosas.

Ao Estado brasileiro é terminantemente vedado promover qualquer religião. Todavia, como se vê, as garantias do Estado secular e da liberdade religiosa não param aí - são mais extensas. Além de impor postura de distanciamento quanto à religião, impedem que o Estado endosse concepções morais religiosas, vindo a coagir, ainda que indiretamente, os cidadãos a observá-las. Não se cuida apenas de ser tolerante com os adeptos de diferentes credos pacíficos e com aqueles que não professam fé alguma. Não se cuida apenas de assegurar a todos a liberdade de frequentar esse ou aquele culto ou seita ou ainda de rejeitar todos eles..$^{23}$ A liberdade religiosa e o Estado laico representam mais do que isso. Significam que as religiões não guiarão o tratamento estatal dispensado a outros direitos fundamentais, tais como o direito à autodeterminação, o direito à saúde física e mental, o direito à privacidade, o

\footnotetext{
${ }^{23}$ Dworkin, Is democracy possible here?, op. cit., p. 60 e 61.
} 
direito à liberdade de expressão, o direito à liberdade de orientação sexual e o direito à liberdade no campo da reprodução.

A questão posta neste processo - inconstitucionalidade da interpretação segundo a qual configura crime a interrupção de gravidez de feto anencéfalo - não pode ser examinada sob os influxos de orientações morais religiosas. Essa premissa é essencial à análise da controvérsia.

Isso não quer dizer, porém, que a oitiva de entidades religiosas tenha sido em vão. Como bem enfatizado no parecer da Procuradoria Geral da República relativamente ao mérito desta arguição de descumprimento de preceito fundamental, "numa democracia, não é legítimo excluir qualquer ator da arena de definição do sentido da Constituição. Contudo, para tornarem-se aceitáveis no debate jurídico, os argumentos provenientes dos grupos religiosos devem ser devidamente 'traduzidos' em termos de razões públicas" (folhas 1.026 e 1.027), ou seja, os argumentos devem ser expostos em termos cuja adesão independa dessa ou daquela crença.

\section{A anencefalia}

As informações e os dados revelados na audiência pública em muito contribuíram para esclarecer o que é anencefalia, inclusive com a apresentação de imagens que facilitaram a compreensão do tema. A anomalia consiste em malformação do tubo neural, caracterizando-se pela ausência parcial do encéfalo e do crânio, resultante de defeito no fechamento do tubo neural durante a formação embrionária.

Como esclareceu o Dr. Heverton Neves Pettersen, ${ }^{24}$ representante da Sociedade Brasileira de Medicina Fetal, o encéfalo é formado pelos hemisférios cerebrais, pelo cerebelo e pelo tronco cerebral. Para o diagnóstico de anencefalia, consoante afirmou o especialista, "precisamos ter ausência dos hemisférios cerebrais, do cerebelo e um tronco cerebral rudimentar. É claro que, durante essa formação, não tendo cobertura da calota craniana, também vai fazer parte do diagnóstico a ausência parcial ou total do crânio" ${ }^{25}$

\footnotetext{
${ }^{24}$ Formado pela Universidade Federal de Minas Gerais, com título de especialista em ginecologia e obstetrícia pela Federação Brasileira das Associações em Ginecologia e Obstetrícia - Febrasgo. Pós-graduado em medicina fetal pelo Hospital King's College - Londres, à época, vice-presidente da Sociedade Brasileira de Medicina Fetal, diretor da Clínica Gennus - Núcleo de Medicina Fetal de Belo Horizonte, e coordenador do Serviço de Medicina Fetal do Hospital Vila da Serra/Nova Lima.

${ }^{25}$ Sessão de audiência pública realizada em 28 de agosto de 2008, transcrição, folha 24.
} 
O anencéfalo, tal qual o morto cerebral, não tem atividade cortical. Conforme exposição do dr. Thomaz Rafael Gollop ${ }^{26}$ - representante da Sociedade Brasileira para o Progresso da Ciência, professor livre-docente em genética médica da Universidade de São Paulo e professor de ginecologia da Faculdade de Medicina de Jundiaí - , no eletroencéfalo dos portadores da anamolia, há uma linha isoelétrica, como no caso de um paciente com morte cerebral. Assim, concluiu o especialista, "isto é a morte cerebral, rigorosamente igual. $\mathrm{O}$ anencéfalo é um morto cerebral, que tem batimento cardíaco e respiração" ${ }^{27}$

O feto anencéfalo mostra-se gravemente deficiente no plano neurológico. Faltam-lhe as funções que dependem do córtex e dos hemisférios cerebrais. Faltam, portanto, não somente os fenômenos da vida psíquica, mas também a sensibilidade, a mobilidade, a integração de quase todas as funções corpóreas. O feto anencefálico não desfruta de nenhuma função superior do sistema nervoso central "responsável pela consciência, cognição, vida relacional, comunicação, afetividade e emotividade" ${ }^{28}$

De acordo com Mário Sebastiani, alguns anencéfalos apresentam:

estímulos dolorosos. Não obstante esta resposta se entende melhor como reflexo doloroso do tronco anencéfalo. Este pormenor é importante posto que implica apenas a existência de um arco reflexo, sem apreciação sensível ao estímulo. A sensação de dor necessita algo mais do que o tronco do cérebro (por exemplo, do tálamo) e o sofrimento exige um substrato neural necessário para perceber, como ameaça, a sensação da dor (neocórtex dos lóbulos frontais). Dado que o anencéfalo carece de tálamo, não há substrato neural para experimentar a dor, da mesma

\footnotetext{
${ }^{26}$ Graduado em medicina pela Faculdade de Medicina da Santa Casa de São Paulo (1971), especialização em ginecologia e obstetrícia pela Faculdade de Medicina da Santa Casa de São Paulo (1973), especialização em genética clínica pela Sociedade Brasileira de Genética Clínica (1995), especialização em título de ginecologia e obstetrícia pela Federação Brasileira das Sociedades de Ginecologia e Obstetrícia (1996), especialização em medicina fetal pela Federação Brasileira das Sociedades de Ginecologia e Obstetrícia (2004), mestrado em ciências biológicas (biologia genética) pela Universidade de São Paulo (1977) e doutorado em ciências biológicas (biologia genética) pela Universidade de São Paulo (1981).

${ }^{27}$ Segundo dia de audiência pública, transcrição, folha 95.

${ }^{28}$ SHEWMON, David A. Anencephaly: selected medical aspects. Hasting Cent Rep, Nova York, 18 (5), p. 11-19, 1988. No mesmo sentido, o dr. Thomaz Rafael Gollop asseverou, durante o pronunciamento na audiência pública de 28 de agosto de 2008, “Esta é a condição de um feto anencefálico: ele não tem crânio nem cérebro. Logo, não pode ter nenhum tipo de sentimento, porque não há uma estação que processe isso" (folha 99).
} 
maneira que carece de substratos cerebrais indispensáveis para o raciocínio, a comunicação, o conhecimento e a sensibilidade em geral. ${ }^{29}$

A anencefalia configura - e quanto a isso não existem dúvidas - doença congênita letal, pois não há possibilidade de desenvolvimento da massa encefálica em momento posterior. ${ }^{30} \mathrm{~A}$ afirmação categórica de que a anencefalia é uma malformação letal funda-se na explanação de especialistas que participaram da audiência pública.

O saudoso deputado federal e professor titular da Universidade de São Paulo e da Universidade de Campinas, dr. José Aristodemo Pinotti, ${ }^{31}$ foi bastante elucidativo ao confirmar que há dois diagnósticos de certeza na ecografia obstétrica: o óbito fetal e a anencefalia. ${ }^{32}$ Ante um diagnóstico de certeza

\footnotetext{
${ }^{29}$ Apud FRANCO, Alberto Silva. Anencefalia - breves considerações médicas, bioéticas, jurídicas e jurídico-penais. Revista dos Tribunais, 833, mar. 2005.

${ }^{30}$ Para confirmar tal entendimento, observem os seguintes trechos das exposições realizadas na audiência pública. Na primeira sessão, o dr. Rodolfo Acatauassú Nunes anotou que "a anencefalia é, ainda, nos dias de hoje, uma doença congênita letal, (...) que exigirá dos pais bastante compreensão devido à inexorabilidade da morte" e complementou que não há cura, no momento atual, para a citada anomalia. Naquela mesma audiência, a sra. Marlene Rossi Severino Nobre, ao ser indagada pelo dr. Luís Roberto Barroso, advogado da arguente, se a anencefalia levava à morte, de maneira peremptória, disse que sim (transcrição, folhas 23, 27 e 55 , respectivamente). Na segunda sessão, o sr. Roberto Luiz D'Ávila consignou que o anencéfalo não se tornará um ser humano, opinião ratificada pelo dr. Jorge Andalaft Neto que, ao conceituar a anencefalia, aduziu ser "letal e multifatorial"; pelo dr. Heverton Pettersen, que considera o "feto anencéfalo um natimorto neurológico"; pelo dr. Salmo Raskin, ao suscitar que padece o anencéfalo de uma "degeneração dos neurônios, e a morte acontece dentro de horas ou dias". Na lição do dr. José Aristodemo Pinotti, um feto anencéfalo não tem cérebro e não tem potencialidade de vida, sendo seu diagnóstico, quando corretamente feito, letal em cem por cento dos casos. A sra. Lenise Aparecida Martins Garcia, mesmo defendendo a tese da inviolabilidade da vida humana, curvou-se ao fato de que apenas um por cento dos anencéfalos sobrevive por cerca de três meses, de acordo com dados de 1987, e o prazo máximo observado foi de um ano e dois meses. O dr. Thomaz Rafael Gollop mostrou-se enfático ao definir o anencéfalo como um morto cerebral, dotado de batimento cardíaco e respiração (transcrição, folhas 7, 16, 30, 60, 70, 82 e 94, respectivamente). A terceira sessão de audiência pública foi aberta com a exposição do então ministro de Estado da Saúde, José Gomes Temporão, que tratou da anencefalia como uma "má-formação incompatível com a vida do feto fora do útero", sendo isso, afirmou, uma certeza médica e científica atestada pela Organização Mundial da Saúde. A dra. Cláudia Werneck sustentou não possuir o anencéfalo expectativa de vida fora do útero (transcrição, folhas 3 e 24, respectivamente). No quarto dia de audiência pública, a dra. Elizabeth Kipman Cerqueira anotou ser o feto anencéfalo um bebê com "curtíssimo" tempo de vida e o dr. Talvane Marins de Moraes mencionou que, na anencefalia, está excluída a vida de relação, inexistindo atividade cortical, correspondendo à morte cerebral (transcrição, folhas 4, 53 e 57, respectivamente).

${ }^{31}$ Médico sanitarista, especialista pelas Universidades de Florença e Milão, Itália, e pelo Institute Gustave Roussy de Paris.

${ }^{32} \mathrm{O}$ dr. Thomaz Rafael Gollop corroborou tal afirmativa, dizendo-nos: “Existem dois diagnósticos em Medicina Fetal que são absolutamente indiscutíveis: óbito fetal e anencefalia" (sessão de audiência pública realizada no dia 28 de agosto de 2008, transcrição, folha 97).
} 
de anencefalia, inexiste presunção de vida extrauterina. “Um feto anencéfalo não tem cérebro, não tem potencialidade de vida". ${ }^{33} \mathrm{Na}$ parte final da fala do ilustre professor, a arguente pediu que fossem confirmadas ou refutadas algumas proposições, entre elas, a de que anencefalia é uma patologia letal em 100\% dos casos. Sua Excelência foi enfático: "Letal, em cem por cento dos casos, quando o diagnóstico é correto". ${ }^{34} \mathrm{E}$ ainda reiterou: "O feto anencéfalo, sem cérebro, não tem potencialidade de vida. Hoje, é consensual, no Brasil e no mundo, que a morte se diagnostica pela morte cerebral. Quem não tem cérebro, não tem vida". ${ }^{35}$

Na mesma linha se pronunciou o já referido representante da Sociedade de Medicina Fetal, dr. Heverton Neves Pettersen, ${ }^{36}$ que afirmou: "nós consideramos o feto anencéfalo um natimorto neurológico. Do ponto de vista técnico, ele não tem sequer o desenvolvimento do sistema nervoso central".

Igualmente, o dr. Thomaz Rafael Gollop, ${ }^{37}$ representante da Sociedade Brasileira para o Progresso da Ciência, foi peremptório: “anencefalia é uma das anomalias mais frequentes, mais prevalentes no nosso meio. Ela é incompatível com a vida, não há atividade cortical, corresponde à morte cerebral. Ninguém tem nenhuma dúvida acerca disso".

Por sua vez, o dr. Jorge Andalaft Neto, representante da Federação Brasileira das Associações de Ginecologia e Obstetrícia, ${ }^{38}$ asseverou: "A anencefalia é incompatível com a vida (...)" ${ }^{39}$ Dessa posição não divergiu o então ministro da Saúde, José Gomes Temporão. ${ }^{40}$ Consoante Sua Excelência, a "anencefalia é uma má-formação incompatível com a vida do feto fora do útero". ${ }^{41}$

De fato, em termos médicos, há dois processos que evidenciam o momento morte: o cerebral e o clínico. O primeiro é a parada total e irreversível

\footnotetext{
${ }^{33}$ Segundo dia de audiência pública, transcrição, folha 75.

${ }^{34}$ Segundo dia de audiência pública, transcrição, folha 76.

${ }^{35}$ Segundo dia de audiência pública, transcrição, folha 77.

${ }^{36}$ Ver nota de rodapé 24.

${ }^{37}$ Ver nota de rodapé 26.

${ }^{38}$ Médico ginecologista e obstetra, mestre e doutor em obstetrícia pela Escola Paulista de Medicina - Unifesp, professor titular de obstetrícia e ginecologia da Universidade de Santo Amaro, membro da Comissão Nacional de Aborto Previsto em Lei da Febrasgo, representante da Federação Brasileira das Associações de Ginecologia e Obstetrícia.

${ }^{39}$ Segundo dia de audiência pública, transcrição, folha 16.

${ }^{40}$ Médico sanitarista, com título de especialista em doenças tropicais pela Universidade Federal do Rio de Janeiro, mestre em saúde pública pela Escola Nacional de Saúde Pública da Fundação Oswaldo Cruz e doutor em medicina social pelo Instituto de Medicina Social da Universidade do Estado do Rio de Janeiro.

${ }^{41}$ Terceiro dia de audiência pública, transcrição, folha 4.
} 
das funções encefálicas, em consequência de causa conhecida, ainda que o tronco cerebral esteja temporariamente em atividade. $O$ segundo é a parada irreversível das funções cardiorrespiratórias, com a finalização das atividades cardíaca e cerebral pela ausência de irrigação sanguínea, resultando em posterior necrose celular. Conforme a Resolução n⿳⺈ 1.480 , de 8 de agosto de 1997, do Conselho Federal de Medicina, os exames complementares a serem observados para a constatação de morte encefálica deverão demonstrar, de modo inequívoco, a ausência de atividade elétrica cerebral ou metabólica cerebral ou, ainda, a inexistência de perfusão sanguínea cerebral.

Não foi por outra razão que o Conselho Federal de Medicina, mediante a Resolução $\mathrm{n}^{\mathrm{0}}$ 1.752/2004, consignou serem os anencéfalos natimortos cerebrais.

$\mathrm{O}$ anencéfalo jamais se tornará uma pessoa. Em síntese, não se cuida de vida em potencial, mas de morte segura. $\mathrm{O}$ fato de respirar e ter batimento cardíaco não altera essa conclusão, até porque, como acentuado pelo dr. Thomaz Rafael Gollop, ${ }^{42}$ a respiração e o batimento cardíaco não excluem o diagnóstico de morte cerebral. ${ }^{43}$

E mais: o coração e a respiração dos anencéfalos perduram por pouco tempo $-75 \%$ não alcançam o ambiente extrauterino. ${ }^{44}$ Dos $25 \%$ restantes, a maior parte tem cessados a respiração e o batimento cardíaco nas primeiras 24 horas e os demais nas primeiras semanas. ${ }^{45}$ Ainda que exista alguma controvérsia quanto a esses percentuais, haja vista o que exposto pela dra.

\footnotetext{
${ }^{42}$ Ver nota de rodapé 26.

${ }^{43}$ Segundo dia de audiência pública, transcrição, folha 96.

${ }^{44}$ Expôs o dr. Gollop que "aproximadamente setenta e cinco por cento dos fetos anencéfalos morrem dentro do útero. As estatísticas oscilam entre cinquenta e setenta e cinco por cento, porque dependem da legislação de cada país (...). Dos vinte e cinco por cento que chegam a nascer, todos têm sobrevida vegetativa, que cessa, na maioria dos casos, dentro de vinte e quatro horas e os demais nas primeiras semanas de sobrevida" (segundo dia de audiência pública, transcrição, folha 97).

${ }_{45}$ Confirmando tais dados, remeto às informações prestadas pelo dr. Rodolfo Acatauassú Nunes, no primeiro dia de audiência pública. Relatou que, consoante dados de Pomerance, a expectativa é de que $47 \%$ das crianças morram no 1 일. $44 \%$ entre um dia e uma semana, $8 \%$ entre uma semana e um mês e $1 \%$ com cerca de três meses (transcrição, folha 27). Igualmente, durante a segunda audiência pública, os drs. Salmo Raskin e Lenise Aparecida Martins Garcia sustentaram, respectivamente, que o feto anencéfalo padece de uma degeneração dos neurônios, circunstância que ocasiona a morte dentro de horas ou dias; que o período máximo encontrado de sobrevida na literatura médica foi de um ano e dois meses, sendo que, ocasionalmente, de sete a dez meses (transcrição, folhas 60 e 82 e 83). No terceiro dia de audiência pública, a sra. Ieda Therezinha do Nascimento Verreschi anotou que de 40 a $60 \%$ dos fetos anencéfalos nascem com vida, mas apenas $8 \%$ sobrevivem por algum tempo (transcrição, folha 35). No quarto dia de audiência pública, o dr. Talvane Marins de Moraes apontou, em consonância com a exposição do dr. Thomaz Rafael Gollop, a ocorrência da morte de $75 \%$ dos fetos anencéfalos ainda dentro do útero, o que importaria em uma gravidez de alto risco (transcrição, folha 58).
} 
Ieda Therezinha ${ }^{46}$ na audiência pública, é indubitável que os anencéfalos resistem muito pouco tempo fora do útero. ${ }^{47}$

No célebre caso de Marcela - suposta portadora de anencefalia que teria sobrevivido por um ano, oito meses e doze dias - , o diagnóstico estava equivocado, consoante informaram renomados especialistas. Não se tratava de anencefalia no sentido corriqueiramente utilizado pela literatura médica, mas de meroencefalia. Vale dizer: o feto possuía partes do cérebro - cerebelo e pedaço do lóbulo temporal - que viabilizavam, embora precariamente, a vida extrauterina. Daí não se poder qualificá-lo, em sentido técnico, como feto anencéfalo, o qual jamais será dotado de tais estruturas. Em audiência pública, o dr. Heverton Neves Pettersen ${ }^{48}$ esclareceu:

E o caso clássico que tivemos no ano passado, da Marcela, está aí a tomografia já apresentada anteriormente, e posso provar aos senhores e a Sua Excelência que é uma falsa ideia de anencéfalo, porque essa criança apresenta, como podemos ver na tomografia, região do cerebelo, tronco cerebral e um pedacinho de lóbulo temporal que faz parte dos hemisférios cerebrais. Então, isso não é diagnóstico de anencefalia. ${ }^{49}$

Mais adiante, ratificou:

Se considerarmos que para o diagnóstico de anencéfalo tem de ter ausência dos hemisférios cerebrais, ausência de calota craniana, ausência de cerebelo e um tronco cerebral rudimentar - e a Marcela apresentava uma formação cerebelar com uma deficiência importante de sua formação, mas facilmente detectável nas imagens apresentadas, como também apresentava resquício do lóbulo temporal, que faz parte dos hemisférios cerebrais, podemos ver que ela não se classifica dentro do diagnóstico de anencéfalo, seria ali uma meroencefalia, uma meroacrania - mero significa porção - , segmento de um anencéfalo..$^{50}$

\footnotetext{
${ }^{46}$ Médica especialista em endocrinologia, professora da aludida disciplina na Escola Paulista de Medicina.

${ }^{47}$ A dra. Ieda Therezinha sustentou que, apesar de a expectativa de vida ser variável no caso dos fetos anencéfalos, há situações "que são nascidos vivos - e esse número é expressivo: 40\% a $60 \%$ - se bem que, após o nascimento, somente $8 \%$ sobrevivem por algum tempo" (terceira audiência pública, transcrição, folha 35).

${ }^{48}$ Ver nota de rodapé 24.

${ }^{49}$ Segundo dia de audiência pública, transcrição, folha 29.

${ }^{50}$ Segundo dia de audiência pública, transcrição, folha 32.
} 
O ponto também foi objeto da exposição do Professor Pinotti. ${ }^{51}$ Ao ser indagado pelo Ministro Gilmar Mendes, então Presidente do Tribunal, o douto especialista respondeu:

Senhor presidente, realmente houve um erro diagnóstico no caso da Marcela. Isso foi comprovado aqui pelo doutor Pettersen, que expôs claramente essa questão. Não era um feto anencéfalo.

Por outro lado, é perfeitamente possível, com aparelhos normais, por ecografistas, com o mínimo de experiência, ser feito um diagnóstico de certeza da anencefalia.

Cumpre rechaçar a assertiva de que a interrupção da gestação do feto anencéfalo consubstancia aborto eugênico, aqui entendido no sentido negativo em referência a práticas nazistas. $\mathrm{O}$ anencéfalo é um natimorto. Não há vida em potencial. Logo não se pode cogitar de aborto eugênico, o qual pressupõe a vida extrauterina de seres que discrepem de padrões imoralmente eleitos. Nesta arguição de descumprimento de preceito fundamental, não se trata de feto ou criança com lábio leporino, ausência de membros, pés tortos, sexo dúbio, Síndrome de Down, extrofia de bexiga, cardiopatias congênitas, comunicação interauricular ou inversões viscerais, enfim, não se trata de feto portador de deficiência grave que permita sobrevida extrauterina. Cuida-se tão somente de anencefalia. Na expressão da dra. Lia Zanotta Machado, "deficiência é uma situação onde é possível estar no mundo; anencefalia, não". ${ }^{22} \mathrm{De}$ fato, a anencefalia mostra-se incompatível com a vida extrauterina, ao passo que a deficiência não.

A corroborar esse entendimento, Cláudia Werneck ${ }^{53}$ - representante da "Escola da Gente", que tem como objetivo a inclusão, na sociedade, de pessoas com deficiência - asseverou que a anencefalia, por conta da total falta de expectativa de vida fora do útero, não pode ser considerada deficiência

\footnotetext{
${ }^{51}$ Ver nota de rodapé 31.

${ }^{52}$ A doutora Lia Zanotta Machado foi ouvida como representante da Rede Nacional Feminista de Saúde, Direitos Sexuais e Direitos Reprodutivos. É graduada em ciências sociais pela Universidade de São Paulo, tem mestrado em sociologia pela mesma Universidade e doutorado em ciências humanas, também pela Universidade de São Paulo, fez cursos de pós-graduação, compõe o Conselho Diretor da Rede Feminista de Saúde, Direitos Sexuais e Direitos Reprodutivos, tendo integrado a Comissão que elaborou o anteprojeto de lei sobre a revisão da legislação punitiva e restritiva ao aborto no Brasil (terceiro dia de audiência pública, transcrição, folha 51).

${ }^{53}$ Jornalista, pós-graduada em Comunicação e Saúde pela Fundação Oswaldo Cruz.
} 
e, portanto, não cabe questionar se existe negação do direito à vida ou discriminação em função de deficiência. ${ }^{54}$ Nas palavras peremptórias da representante da entidade que se dedica a combater discriminação contra deficientes, "é impossível constatar discriminação com base na deficiência quando não há expectativa de vida fora do útero". ${ }^{55}$

Destarte, afasto, desde logo, a aplicação, na espécie, dos preceitos da Convenção sobre Direitos da Criança das Nações Unidas, ${ }^{56}$ especialmente os dispositivos abaixo transcritos para efeito de documentação:

Art. 6o

1. Os Estados Partes reconhecem que toda criança tem o direito inerente à vida.

2. Os Estados Partes assegurarão ao máximo a sobrevivência e o desenvolvimento da criança.

Art. 23

1. Os Estados Partes reconhecem que a criança portadora de deficiências físicas ou mentais deverá desfrutar de uma vida plena e decente em condições que garantam sua dignidade, favoreçam sua autonomia e facilitem sua participação ativa na comunidade.

Os Estados Partes reconhecem o direito da criança deficiente de receber cuidados especiais e, de acordo com os recursos disponíveis e sempre que a criança ou seus responsáveis reúnam as condições requeridas, estimularão e assegurarão a prestação da assistência solicitada, que seja adequada ao estado da criança e às circunstâncias de seus pais ou das pessoas encarregadas de seus cuidados.

Do mesmo modo, revela-se inaplicável a Constituição Federal no que determina a proteção à criança e ao adolescente, devendo a eles ser viabilizado o direito à vida, à saúde, à alimentação, à educação, ao lazer, à profissionalização, à cultura, à dignidade, ao respeito, à liberdade e à convivência familiar e comunitária, ficando a salvo de toda forma de negligência, discriminação, exploração, violência, crueldade e opressão. Ora, é inimaginável falar-se desses

\footnotetext{
${ }^{54}$ Como bem afirma Débora Diniz, não há pessoas anencéfalas no mundo. É um desrespeito à comunidade deficiente compará-los aos anencéfalos. In: Em nome da mãe. Entrevista concedida à revista Época, ed. 321, 17 de julho de 2004. Disponível em: <http://revistaepoca.com.br>.

${ }^{55}$ Terceiro dia de audiência pública, transcrição, folha 24.

${ }^{56}$ Ratificada pelo Estado brasileiro em 24 de setembro de 1990. Informação disponível na página eletrônica do Ministério das Relações Exteriores.
} 
objetivos no caso de feto anencéfalo, presente a impossibilidade de, ocorrendo o parto, vir-se a cogitar de criança e, posteriormente, de adolescente.

Ainda sobre os contornos da anomalia, cumpre registrar que a anencefalia pode ser diagnosticada na $12^{\mathrm{a}}$ semana de gestação, ${ }^{57}$ por meio de ultrassonografia, estando a rede pública de saúde capacitada para fazê-lo. Geralmente, os médicos preferem repetir o exame em uma ou duas semanas para confirmação. Trata-se de um diagnóstico de certeza, consoante enfatizaram doutos especialistas na audiência pública. A par dos depoimentos já reproduzidos, convém realçar as palavras do dr. Thomaz Rafael Gollop: ${ }^{58}$

A ultrassonografia disponível, sim, no Sistema Único de Saúde é $100 \%$ segura. Existem dois diagnósticos em Medicina Fetal que são absolutamente indiscutíveis: óbito fetal e anencefalia. Não há nenhuma dúvida para um médico minimamente formado estabelecer esse diagnóstico.

O ex-ministro da Saúde José Gomes Temporão ${ }^{59}$ rechaçou qualquer dúvida acerca da capacidade da rede pública de proceder ao diagnóstico. Disse Sua Excelência:

O Sistema Único de Saúde tem plenas condições de oferecer, e oferece, diagnóstico seguro às mulheres durante o pré-natal. A imagem ecográfica é clara em diagnosticar um feto com anencefalia. $\mathrm{Na}$ Medicina fetal, há duas certezas de diagnóstico por imagem: o óbito fetal e a anencefalia.

(...)

No geral, o diagnóstico de anencefalia no feto é dado em torno da décima segunda semana de gestação. Os exames de rotina do pré-natal detectam a má-formação fetal e a mulher é informada do diagnóstico. Ela é, então, convidada a repetir os exames, que, em geral, são realizados por outras equipes médicas. Nos municípios onde existem hospitais de referência em Medicina fetal, a mulher é encaminhada para esses serviços. Posso assegurar que o diagnóstico de anencefalia resulta de exames feitos por mais de um médico e que o atendimento à paciente é conduzido por equipes de saúde multidisciplinares.

\footnotetext{
${ }^{57}$ Há estudos que indicam que, em razão da imensa qualidade dos exames de ultrassonografias, é possível identificar a malformação já na oitava semana gestacional. Nesse sentido, pronunciou-se o representante da Sociedade Brasileira de Medicina Fetal, doutor Heverton Neves Pettersen, na sessão de audiência pública realizada em 28 de agosto de 2008.

${ }^{58}$ Ver nota de rodapé 26.

${ }^{59}$ Ver nota de rodapé 40.
} 
Constata-se que, para parcela significante de renomados especialistas, há diagnóstico de certeza, estando a rede pública de saúde capacitada para realizá-lo, o que, por óbvio, não impede que órgãos e entidades competentes estabeleçam protocolos e cuidados a serem tomados para torná-lo ainda mais seguro. Tal medida será salutar.

Expostas as balizas da anencefalia, passemos aos possíveis argumentos favoráveis à proteção do anencéfalo, sempre tendo presente a laicidade do Estado.

\section{Doação de órgãos de anencéfalos}

Ao contrário do que sustentado por alguns, não é dado invocar, em prol da proteção dos fetos anencéfalos, a possibilidade de doação de seus órgãos. ${ }^{60}$ E não se pode fazê-lo por duas razões. A primeira por ser vedado obrigar a manutenção de uma gravidez tão somente para viabilizar a doação de órgãos, sob pena de coisificar a mulher e ferir, a mais não poder, a sua dignidade. A segunda por revelar-se praticamente impossível o aproveitamento dos órgãos de um feto anencéfalo. Essa última razão reforça a anterior, porquanto, se é inumano e impensável tratar a mulher como mero instrumento para atender a certa finalidade, avulta-se ainda mais grave se a chance de êxito for praticamente nula.

Kant, em Fundamentação à metafísica dos costumes, ${ }^{61}$ assevera:

o homem, e, de maneira geral, todo o ser racional, existe como fim de si mesmo, não só como meio para o uso arbitrário desta ou daquela vontade (...). Os seres cuja existência depende, não em verdade da nossa vontade, mas da natureza, têm, contudo, se são seres irracionais, apenas um valor relativo como meios, e por isso se chamam coisas, ao

\footnotetext{
${ }^{60} \mathrm{O}$ ex-procurador-geral da República, dr. Cláudio Lemos Fonteles, em manifestação de agosto de 2004, asseverou que o "pleito da autora, titulado por órgão que representa profissionais da área da saúde, impede possa acontecer a doação de órgãos do bebê anencéfalo a tantos outros bebês que, se têm normal formação do cérebro, todavia têm grave deficiência nos olhos, nos pulmões, nos rins, no coração, órgãos estes plenamente saudáveis no bebê anencéfalo, cuja morte prematura frustrará a vida de outros bebês, assim também condenados a morrer, ou a não ver" (folha 218).

${ }^{61}$ p. 135.
} 
passo que os seres racionais se chamam pessoas, porque a sua natureza os distingue já como fins em si mesmos, quer dizer, como algo que não pode ser empregado como simples meio.

A mulher, portanto, deve ser tratada como um fim em si mesma, e não, sob uma perspectiva utilitarista, como instrumento para geração de órgãos e posterior doação. Ainda que os órgãos de anencéfalos fossem necessários para salvar vidas alheias - premissa que não se confirma, como se verá - , não se poderia compeli-la, com fundamento na solidariedade, a levar adiante a gestação, impondo-lhe sofrimentos de toda ordem. Caso contrário, ela estaria sendo vista como simples objeto, em violação à condição de humana.

Maíra Costa Fernandes pondera sabiamente ser a doação ato intrinsecamente voluntário, jamais imposto, e salienta não aceitar o direito brasileiro sequer a obrigatoriedade de doação de sangue ou de medula óssea - atos capazes de salvar inúmeras pessoas, os quais não reclamam sacrifício próximo ao da mulher obrigada a dar continuidade à gestação de um anencéfalo. Nessa linha, afirma, "qualquer restrição aos direitos da gestante sobre o próprio corpo retira toda a magnitude do ato de doar órgãos, espontâneo em sua essência". ${ }^{62}$

Débora Diniz ${ }^{63}$ também é bastante precisa ao sintetizar a questão: ${ }^{64}$

O dever de gestação se converte no dever de dar a luz a um filho para enterrá-lo. Penalizá-la com a mantença da gravidez, para a finalidade exclusiva do transplante de órgãos do anencéfalo significa uma lesão à autonomia da mulher, em relação a seu corpo e à sua dignidade como pessoa (...).

A circunstância de o feto anencéfalo ser comumente portador de diversas outras anomalias e de possuir órgãos menores do que os de fetos saudáveis praticamente impossibilita a doação de órgãos, conforme elucidaram em

\footnotetext{
62 FERNANDES, Maíra Costa. Interrupção de gravidez de feto anencéfalo: uma análise constitucional. In: SARMENTO, Daniel; PIOVESAN, Flávia (Coord.). Nos limites da vida: aborto, clonagem humana e eutanásia sob a perspectiva dos direitos humanos. Rio de Janeiro: Lumen Juris, 2007. p. 111-158, p. 150 e 152.

${ }^{63}$ Antropóloga, mestre e doutora em antropologia pela Universidade de Brasília, representante do Instituto de Bioética, Direitos Humanos e Gênero - Anis.

${ }^{64}$ In: O luto das mulheres brasileiras. Jornal da Febrasgo, São Paulo, out. 2004. p. 8-9. Disponível em: <www.febrasgo.org.br/anencefalia3.htm. Acesso em: 14 set. 2010.
} 
audiência pública os drs. Salmo Raskin ${ }^{65}$ e José Aristodemo Pinotti. ${ }^{66}$ Cabe reproduzir, no ponto, os esclarecimentos do dr. Salmo Raskin, representante da Sociedade Brasileira de Genética Médica: ${ }^{67}$

Os fetos anencefálicos não podem ser doadores de órgãos pelo que eu expus, porque são portadores, em grande parcela das vezes, de múltiplas malformações; referi-me àquelas que são detectáveis pelos métodos, sem falar nas alterações íntimas dos tecidos do corpo, que não podem ser detectadas, a não ser que se faça um exame extremamente complexo. Além disso, os órgãos dos fetos anencefálicos são menores, tanto que cerca de $80 \%$ dos anencefálicos nascem com retardo de crescimento intrauterino. De modo que os órgãos deles não são órgãos que possam ser aproveitados para o transplante.

Não se olvida ter o Conselho Federal de Medicina, em 8 de setembro de 2009, aprovado a Resolução no 1.752 , cujo teor autoriza os médicos a efetuarem transplantes de órgãos de fetos anencéfalos. Porém, segundo o Parecer $\mathrm{n}^{\mathrm{o}}$ 24/2003, do qual resultou a Resolução:

Os critérios de morte encefálica, constantes da Resolução, CFM n no 1.480/97, são baseados na ausência de atividade de todo o cérebro, incluindo, obviamente, o tronco cerebral. No anencéfalo não existe a possibilidade de aplicação dos critérios relativos a exames complementares de diagnóstico de morte encefálica, constantes nos artigos $6^{\circ}$ e 7o da resolução supracitada, sejam os métodos gráficos (eletroencefalograma), sejam os métodos circulatórios, pela ausência de neocórtex, anormalidade da rede vascular cerebral e ausência de calota craniana. Restaria a utilização dos parâmetros clínicos de morte encefálica (coma aperceptivo com ausência de atividade motora supraespinal e apneia), respeitando-se a idade mínima de sete dias (artigos 4o e 5ํㅡ). Entretanto, corroborando a total inadequação para essas situações, os anencéfalos

\footnotetext{
${ }^{65}$ Médico pediatra e geneticista, especialista em genética molecular pela Universidade de Vanderbilt, Estados Unidos, especialista em genética clínica pela Sociedade Brasileira de Genética Médica, doutor em genética pela Universidade Federal do Paraná.

${ }^{66}$ Ver nota de rodapé 31.

${ }^{67}$ Segundo dia de audiência pública, transcrição, folha 64.
} 
morrem clinicamente durante a primeira semana de vida. Nesse estado, os órgãos estão em franca hipoxemia, "tornando-se inúteis para uso em transplantes". (grifei)

A solidaderiedade não pode, assim, ser utilizada para fundamentar a manutenção compulsória da gravidez de feto anencéfalo, seja porque violaria o princípio da dignidade da pessoa humana, seja porque os órgãos dos anencéfalos não são passíveis de doação.

\section{Direito à vida dos anencéfalos}

Igualmente, senhor presidente, não é dado invocar o direito à vida dos anencéfalos. Anencefalia e vida são termos antitéticos. Conforme demonstrado, o feto anencéfalo não tem potencialidade de vida. Trata-se, na expressão adotada pelo Conselho Federal de Medicina e por abalizados especialistas, de um natimorto cerebral. Por ser absolutamente inviável, o anencéfalo não tem a expectativa nem é ou será titular do direito à vida, motivo pelo qual aludi, no início do voto, a um conflito apenas aparente entre direitos fundamentais. Em rigor, no outro lado da balança, em contraposição aos direitos da mulher, não se encontra o direito à vida ou à dignidade humana de quem está por vir, justamente porque não há ninguém por vir, não há viabilidade de vida.

Aborto é crime contra a vida. Tutela-se a vida em potencial. No caso do anencéfalo, repito, não existe vida possível. Na expressão do ministro Joaquim Barbosa, constante do voto que chegou a elaborar no Habeas Corpus no 84.025/RJ, o feto anencéfalo, mesmo que biologicamente vivo, porque feito de células e tecidos vivos, é juridicamente morto, não gozando de proteção jurídica e, acrescento, principalmente de proteção jurídico-penal. Nesse contexto, a interrupção da gestação de feto anencefálico não configura crime contra a vida - revela-se conduta atípica.

Tal assertiva fica corroborada pelos ensinamentos de Nelson Hungria, que, na década de 50, já condicionava a configuração do tipo penal aborto à existência de potencialidade de vida. Diz ele: ${ }^{68}$

\footnotetext{
${ }^{68}$ Rio de Janeiro: Forense, 1958. v. V, p. 15, 286 e 287.
} 
O interesse jurídico relativo à vida e à pessoa é lesado desde que se impede a aquisição da vida e da personalidade civil a um feto capaz de adquiri-las. Por outro lado, ainda que não se pudesse falar de vida em sentido especial ou próprio, relativamente ao feto, não deixaria de ser verdade que este é dotado de vida intrauterina ou biológica, que também é vida, em sentido genérico. Quem pratica um aborto não opera 'in materiam brutam', mas contra um homem na 'antessala' da vida civil. O feto é uma pessoa virtual, um cidadão em germe. É um homem 'in spem'. Entre o infanticídio (eliminação de vida extrauterina) e o aborto (eliminação da vida intrauterina) a diferença é de apenas um grau, ou, como dizia CARRARA, de quantidade natural e de quantidade política.

E prossegue:

caso de gravidez extrauterina, que representa um estado patológico, a sua interrupção não pode constituir o crime de aborto. Não está em jogo a vida de outro ser, não podendo o produto da concepção atingir normalmente vida própria, de modo que as consequências dos atos praticados se resolvem unicamente contra a mulher. $\mathrm{O}$ feto expulso (para que se caracterize o aborto) deve ser um produto fisiológico, e não patológico. Se a gravidez se apresenta como um processo verdadeiramente mórbido, de modo a não permitir sequer uma intervenção cirúrgica que pudesse salvar a vida do feto, não há falar-se em aborto, para cuja existência é necessária a presumida possibilidade de continuação da vida do feto. (grifei) ${ }^{69}$

Sábias palavras de Nelson Hungria, a repercutirem neste julgamento, verificado cerca de sessenta anos após.

É de conhecimento corrente que, nas décadas de 30 e 40, a medicina não possuía os recursos técnicos necessários para identificar previamente a anomalia fetal incompatível com a vida extrauterina. ${ }^{70}$ A literalidade do Código Penal de 1940 certamente está em harmonia com o nível de diagnósticos médicos existentes à época, o que explica a ausência de dispositivo que preveja

\footnotetext{
${ }^{69}$ Ibid., p. 297-298.

${ }^{70}$ Marcos Valentin Frigério examina o histórico do surgimento e dos desenvolvimentos dos diagnósticos da medicina fetal. Ob. cit. p. 272-275.
} 
expressamente a atipicidade da interrupção da gravidez de feto anencefálico. Não nos custa lembrar: estamos a tratar do mesmíssimo legislador que, para proteger a honra e a saúde mental ou psíquica da mulher - da mulher, repito, não obstante a visão machista então reinante ${ }^{71}-$, estabeleceu como impunível o aborto provocado em gestação oriunda de estupro, ou seja, quando o feto é plenamente viável.

Senhor presidente, mesmo à falta de previsão expressa no Código Penal de 1940, parece-me lógico que o feto sem potencialidade de vida não pode ser tutelado pelo tipo penal que protege a vida. No ponto, são extremamente pertinentes as palavras de padre Antônio Vieira com as quais iniciei este voto. O tempo e as coisas não param. Os avanços alcançados pela sociedade são progressivos. Inconcebível, no campo do pensar, é a estagnação. Inconcebível é o misoneísmo, ou seja, a aversão, sem justificativa, ao que é novo.

Aliás, no julgamento da referida e paradigmática Ação Direta de Inconstitucionalidade $\mathrm{n}^{\mathrm{o}}$ 3.510/DF, acerca da pesquisa com células-tronco embrionárias, um dos temas espinhosos enfrentados pelo Plenário foi o do que pode vir a ser considerado vida e quando esta tem início. Ao pronunciar-me quanto à questão do princípio da vida, mencionei a possibilidade de adotar diversos enfoques, entre os quais: o da concepção, o da ligação do feto à parede do útero (nidação), o da formação das características individuais do feto, o da percepção pela mãe dos primeiros movimentos, o da viabilidade em termos de persistência da gravidez e o do nascimento. Aludi ainda ao fato de, sob o

\footnotetext{
${ }^{71}$ Cito como exemplos de evidência da visão machista reinante a redação original dos artigos 215 e 216 do Código Penal, nos quais constava a expressão "mulher honesta" como elementar dos crimes de posse mediante fraude e de atentado ao pudor mediante fraude, e a do artigo 217, revogado pela Lei no $11.106 / 2005$, em que se tipificava como crime a sedução de mulher virgem, menor de dezoito anos e maior de catorze. No mesmo sentido, o antigo Código Civil, Lei $n^{\circ}$ 3.071/16, previa como erro essencial sobre a pessoa do outro cônjuge o "defloramento da mulher, ignorado pelo marido" (artigo 219, inciso IV), dispunha ainda que o marido fosse o chefe da sociedade conjugal, função que exercia com a colaboração da mulher, competindo-lhe, entre outras, a representação legal da família e a administração dos bens comuns e dos particulares da mulher (artigo 233), e que a autorização pelo marido para a compra, ainda a crédito, das coisas necessárias à economia doméstica era presumida (artigo 247, inciso I). Existia a previsão do regime dotal como espécie de regime de bens entre os cônjuges, em franca demonstração da situação jurídica inferior da mulher (artigos 278 a 311) e a de competir ao marido, durante o casamento, o exercício do pátrio poder (artigos 380, cabeça, e 385). Interessante anotar que, somente em 1962, com a vigência da Lei no 4.121, a mulher tornou-se capacitada para litigar em juízo civil ou comercial e aceitar mandato. Destaco que as restrições ao pleno exercício do voto feminino só foram eliminadas no Código Eleitoral de 1934. No entanto, o Código não tornava obrigatório o voto feminino. Apenas o masculino. O voto feminino, sem restrições, só passou a ser obrigatório em 1946.
} 
ângulo biológico, o início da vida pressupor não só a fecundação do óvulo pelo espermatozoide como também a viabilidade, elemento inexistente quando se trata de feto anencéfalo, considerado pela medicina como natimorto cerebral, consoante opinião majoritária.

Ao término do julgamento, o Supremo, na dicção do ministro Ayres Britto, proclamou acertadamente:

O Magno Texto Federal não dispõe sobre o início da vida humana ou o preciso instante em que ela começa. Não faz de todo e qualquer estágio da vida humana um autonomizado bem jurídico, mas da vida que já é própria de uma concreta pessoa, porque nativiva (teoria "natalista", em contraposição às teorias "concepcionista" ou da "personalidade condicional"). E quando se reporta a "direitos da pessoa humana" e até dos "direitos e garantias individuais" como cláusula pétrea está falando de direitos e garantias do indivíduo-pessoa, que se faz destinatário dos direitos fundamentais "à vida, à liberdade, à igualdade, à segurança e à propriedade", entre outros direitos e garantias igualmente distinguidos com o timbre da fundamentalidade (como direito à saúde e ao planejamento familiar). Mutismo constitucional hermeneuticamente significante de transpasse de poder normativo para a legislação ordinária. A potencialidade de algo para se tornar pessoa humana já é meritória o bastante para acobertá-la, infraconstitucionalmente, contra tentativas levianas ou frívolas de obstar sua natural continuidade fisiológica. Mas as três realidades não se confundem: o embrião é o embrião, o feto é o feto e a pessoa humana é a pessoa humana. Donde não existir pessoa humana embrionária, mas embrião de pessoa humana. (...). O Direito infraconstitucional protege por modo variado cada etapa do desenvolvimento biológico do ser humano. Os momentos da vida humana anteriores ao nascimento devem ser objeto de proteção pelo direito comum. O embrião pré-implanto é um bem a ser protegido, mas não uma pessoa no sentido biográfico a que se refere a Constituição. (Grifei)

Da leitura, destaco dois trechos. No primeiro, este Supremo Tribunal proclamou que a Constituição "quando se reporta a 'direitos da pessoa humana' e até dos 'direitos e garantias individuais' como cláusula pétrea está falando de direitos e garantias do indivíduo-pessoa, que se faz destinatário dos direitos fundamentais 'à vida, à liberdade, à igualdade, à segurança e à 
propriedade'"'. É certo, senhor presidente, que, no caso do anencéfalo, não há, nem nunca haverá, indivíduo-pessoa.

No segundo trecho, este Tribunal assentou que "a potencialidade de algo para se tornar pessoa humana já é meritória o bastante para acobertála, infraconstitucionalmente, contra tentativas levianas ou frívolas de obstar sua natural continuidade fisiológica". Ora, inexistindo potencialidade para tornar-se pessoa humana, não surge justificativa para a tutela jurídico-penal, com maior razão quando eventual tutela esbarra em direitos fundamentais da mulher, como se verá adiante.

Enfim, cumpre tomar de empréstimo o conceito jurídico de morte cerebral previsto na Lei $n^{\circ} 9.434 / 97,{ }^{72}$ para concluir ser de todo impróprio falar em direito à vida intrauterina ou extrauterina do anencéfalo, o qual é um natimorto cerebral.

De qualquer sorte, senhor presidente, aceitemos - apenas por amor ao debate e em respeito às opiniões divergentes presentes na sociedade e externadas em audiência pública - a tese de que haveria o direito à vida dos anencéfalos, vida predominantemente intrauterina. Nesse contexto, uma vez admitido tal direito - premissa com a qual não comungo, conforme exposto à exaustão - , deve-se definir se a melhor ponderação dos valores em jogo conduz à limitação da dignidade, da liberdade, da autodeterminação, da saúde, dos direitos sexuais e reprodutivos de milhares de mulheres em favor da preservação do feto anencéfalo, ou o contrário.

\footnotetext{
${ }^{72}$ Art. 3o A retirada post mortem de tecidos, órgãos ou partes do corpo humano destinados a transplante ou tratamento deverá ser precedida de diagnóstico de morte encefálica, constatada e registrada por dois médicos não participantes das equipes de remoção e transplante, mediante a utilização de critérios clínicos e tecnológicos definidos por resolução do Conselho Federal de Medicina.

Resolução no 1.480/97 do Conselho Federal de Medicina:

Art. 1․ A morte encefálica será caracterizada através da realização de exames clínicos e complementares durante intervalos de tempo variáveis, próprios para determinadas faixas etárias.

Art. 3‥ A morte encefálica deverá ser consequência de processo irreversível e de causa conhecida. Art. 4․ Os parâmetros clínicos a serem observados para constatação de morte encefálica são: coma aperceptivo com ausência de atividade motora supraespinal e apneia.

Art. 6․ Os exames complementares a serem observados para constatação de morte encefálica deverão demonstrar de forma inequívoca:
a) ausência de atividade elétrica cerebral ou,
b) ausência de atividade metabólica cerebral ou,
c) ausência de perfusão sanguínea cerebral. 


\subsection{O caráter não absoluto do direito à vida}

Inexiste hierarquia do direito à vida sobre os demais direitos, o que é inquestionável ante o próprio texto da Constituição da República, cujo artigo 5º, inciso XLVII, admite a pena de morte em caso de guerra declarada na forma do artigo 84, inciso XIX. Corrobora esse entendimento o fato de o Código Penal prever, como causa excludente de ilicitude ou antijuridicidade, o aborto ético ou humanitário - quando o feto, mesmo sadio, seja resultado de estupro. Ao sopesar o direito à vida do feto e os direitos da mulher violentada, o legislador houve por bem priorizar estes em detrimento daquele - e, até aqui, ninguém ousou colocar em dúvida a constitucionalidade da previsão.

Aliás, no direito comparado, outros Tribunais Constitucionais já assentaram não ser a vida um valor constitucional absoluto. Apenas a título ilustrativo, vale mencionar decisão da Corte Constitucional italiana em que se declarou a inconstitucionalidade parcial de dispositivo que criminalizava o aborto sem estabelecer exceção alguma. Eis o que ficou consignado:

\section{(...) o interesse constitucionalmente protegido relativo ao nascituro} pode entrar em colisão com outros bens que gozam de tutela constitucional e que, por consequência, a lei não pode dar ao primeiro uma prevalência absoluta, negando aos segundos adequada proteção. E é exatamente este vício de ilegitimidade constitucional que, no entendimento da Corte, invalida a atual disciplina penal do aborto...

Ora, não existe equivalência entre o direito não apenas à vida, mas também à saúde de quem já é pessoa, como a mãe, e a salvaguarda do embrião, que pessoa ainda deve tornar-se. ${ }^{73}$

Além de o direito à vida não ser absoluto, a proteção a ele conferida comporta diferentes gradações consoante enfatizou o Supremo no julgamento da Ação Direta de Inconstitucionalidade nํㅜ 3.510. Para reforçar essa conclusão, basta observar a pena cominada ao crime de homicídio (de seis a vinte anos) e de aborto provocado pela gestante ou com seu consentimento (de um a três

\footnotetext{
${ }^{73}$ Trecho extraído de SARMENTO, Daniel. Livres e iguais: estudos de direito constitucional. Rio de Janeiro: Lumen Juris, 2006. p. 103.
} 
anos), ${ }^{74}$ a revelar que o direito à vida ganha contornos mais amplos, atraindo proteção estatal mais intensa, à medida que ocorre o desenvolvimento.

Nas palavras da Ministra Cármen Lúcia, "há que se distinguir (...) ser humano de pessoa humana (...) O embrião é (...) ser humano, ser vivo, obviamente (...) Não é, ainda, pessoa, vale dizer, sujeito de direitos e deveres, o que caracteriza o estatuto constitucional da pessoa humana". ${ }^{75}$

Assim, ainda que se conceba a existência do direito à vida de fetos anencéfalos - repito, premissa da qual discordo - , deve-se admitir ser a tutela conferida a tal direito menos intensa do que aquela própria às pessoas e aos fetos em geral. Mostra-se um equívoco equiparar um feto natimorto cerebral, possuidor de anomalia irremediável e fatal, que, se sobreviver ao parto, o será por poucas horas ou dias, a um feto saudável. Simplesmente, aquele não se iguala a este. Se a proteção ao feto saudável é passível de ponderação com direitos da mulher, com maior razão o é eventual proteção dada ao feto anencéfalo.

Passemos aos direitos da mulher que se contrapõem à preservação do feto anencéfalo.

\section{Direito à saúde, à dignidade, à liberdade, à autonomia, à privacidade}

A Organização Mundial de Saúde, no Preâmbulo do ato fundador, firmado em 22 de julho de 1946, define saúde como "o estado de completo bem-estar físico, mental e social e não simplesmente como a ausência de enfermidade".${ }^{76}$ No Plano de Ação da Conferência Mundial sobre população e desenvolvimento, realizado na cidade do Cairo, Egito, em 1994, além de reconhecerem-se como direitos humanos os sexuais e os reprodutivos, estabeleceuse como princípio que "toda pessoa tem direito ao gozo do mais alto padrão possível de saúde física e mental".

\footnotetext{
${ }^{74}$ Art. 121. Matar alguém: Pena - reclusão, de seis a vinte anos. Art. 123 - Matar, sob a influência do estado puerperal, o próprio filho, durante o parto ou logo após: Pena - detenção, de dois a seis anos. Art. 124 - Provocar aborto em si mesma ou consentir que outrem lho provoque: Pena - detenção, de um a três anos.

${ }^{75}$ Vida digna: direito, ética e ciência. In: ROCHA, Cármen Lúcia Antunes (Coord.). O direito à vida digna. Belo Horizonte: Fórum, 2004. p. 22-34, p. 22.

${ }^{76} \mathrm{O}$ ato constituidor da Organização Mundial da Saúde encontra-se disponível no sítio eletrônico: <http://apps.who.int/gb/bd/PDF/bd47/EN/constitution-en.pdf>. Acesso em: 4 maio 2011.
} 
Sob o ângulo da saúde física da mulher, toda gravidez acarreta riscos. ${ }^{77}$ Há alguma divergência se a gestação de anencéfalo é mais perigosa do que a de um feto sadio. A dra. Elizabeth Kipman Cerqueira, ${ }^{78}$ ouvida no último dia de audiência pública, enfatizou os riscos inerentes à antecipação do parto e questionou a óptica segundo a qual a manutenção da gravidez do feto anencéfalo mostra-se mais perigosa. ${ }^{79}$

O dr. Jorge Andalaft Neto, mestre e doutor em obstetrícia pela Escola Paulista de Medicina, representante da Federação Brasileira das Associações de Ginecologia e Obstetrícia, trouxe, por sua vez, dados da Organização Mundial de Saúde e do Comitê da Associação de Ginecologia e Obstetrícia Americana reveladores de que a gestação de feto anencéfalo envolve maiores riscos. De acordo com as informações por ele apresentadas, impor a manutenção da gravidez implica o aumento da morbidade bem como dos riscos inerentes à gestação, ao parto e ao pós-parto e resulta em consequências psicológicas severas.

Consoante defendeu o então ministro da Saúde, José Gomes Temporão, ${ }^{80}$ a gravidez de feto anencéfalo "pode levar a intercorrências durante a gestação, colocando a saúde da mãe em risco num percentual maior do que na gestação normal". O dr. Talvane Marins de Moraes, ${ }^{81}$ igualmente, realçou ser de alto risco a gravidez de anencéfalo, até pela probabilidade bastante aumentada de o feto perecer dentro do útero. ${ }^{82}$

Nessa linha, também são os esclarecimentos da Federação Brasileira das Associações de Ginecologia e Obstetrícia - Febrasgo. Segundo relatado,

\footnotetext{
${ }^{77}$ Conforme informações prestadas no segundo dia de audiência pública - folha 7. O doutor Roberto Luiz D'Ávila, em manifestação no segundo dia de audiência pública, destacou ser alta a taxa de mortalidade materna devido à presença de doenças hipertensivas, hemorragias e infecções, inclusive, em gestações de fetos viáveis (transcrição, folha 12).

${ }^{78}$ Médica especialista em ginecologia e obstetrícia, ex-secretária de Saúde do município de Jacareí/ SP, à época, diretora do Centro Interdisciplinar de Estudos Bioéticos do Hospital São Francisco, São Paulo.

${ }^{79}$ Consoante informações prestadas na sessão de audiência pública realizada em 16 de setembro (transcrição, folhas 4, 5 e 8). Há tanta divergência acerca do fato de a gravidez de feto anencéfalo constituir ou não um risco maior à vida materna que o doutor Dernival da Silva Brandão chegou a sustentar que "a criança anencéfala - vejam bem - não causa perigo à vida da sua mãe mais do que uma gestação gemelar" (transcrição, folha 81).

${ }^{80}$ Ver nota de rodapé 40 .

${ }^{81}$ Médico especialista em psiquiatria forense, livre-docente e doutor em psiquiatria pela Universidade Federal do Rio de Janeiro, membro das Câmaras Técnicas de Perícia Médica e Medicina Legal do Conselho Regional de Medicina do Rio de Janeiro, representante da Associação Brasileira de Psiquiatria.

${ }_{82}$ À folha 1.409 da transcrição da sessão de audiência pública realizada em 16 de setembro, temse “(...) É outro dado de saúde pública também. Quer dizer, uma gravidez anencéfala é uma gravidez de alto risco, porque o feto vai morrer intraútero muitas vezes".
} 
nesse tipo de gestação, é comum a apresentação fetal anômala - pélvico transverso, de face e oblíquos - ante a dificuldade de insinuação do polo fetal no estreito inferior da bacia. ${ }^{83}$ Isso ocorre porque a cabeça do feto portador de anencefalia não consegue se "encaixar" de maneira adequada na pélvis, o que importa em um trabalho de parto mais prolongado, doloroso, levando, comumente, à realização de cesariana. Em 50\% dos casos, a poli-hidrâmnio, ou aumento do líquido amniótico, está ligada à anencefalia, tendo em vista a maior dificuldade de deglutição do feto portador de referida anomalia, situação que também pode conduzir à hipertensão, ao trabalho de parto prematuro, à hemorragia pós-parto e ao prolapso de cordão.

Outros fatores associados à gestação de feto anencéfalo são doença hipertensiva específica de gravidez (DHEG) - que compromete o bem-estar físico da gestante - , maior incidência de hipertensão, diabetes, aumento de cerca de $58 \%$ de partos prematuros, elevação em $22 \%$ do número de casos de gravidez prolongada. Na literatura médica, há registro de gestação que se estendeu por mais de um ano, no qual o feto continuou em movimento até a hora do parto. Nas situações em que se observa a associação com poli-hidrâmnio e trabalho de parto prolongado, a incidência de hipotonia e hemorragia no pós-parto é de três a cinco vezes maior. Mais uma consequência identificada eventualmente nesse tipo de gravidez é o sangramento de grande monta no puerpério.

Constata-se a existência de dados merecedores de confiança que apontam riscos físicos maiores à gestante portadora de feto anencéfalo do que os verificados na gravidez comum.

Sob o aspecto psíquico, parece incontroverso - impor a continuidade da gravidez de feto anencéfalo pode conduzir a quadro devastador, como o experimentado por Gabriela Oliveira Cordeiro, que figurou como paciente no emblemático Habeas Corpus no 84.025/RJ, da relatoria do ministro Joaquim Barbosa. A narrativa dela é reveladora: ${ }^{84}$

(...) Um dia eu não aguentei. Eu chorava muito, não conseguia parar de chorar. O meu marido me pedia para parar, mas eu não conseguia. Eu saí na rua correndo, chorando, e ele atrás de mim. Estava chovendo, era meia-noite. Eu estava pensando no bebê. Foi na semana anterior ao parto. Eu comecei a sonhar. O meu marido também. Eu sonhava com

\footnotetext{
${ }^{83} \mathrm{O}$ inteiro teor do documento expedido pela Febrasgo encontra-se disponível em: <www. febrasgo.org.br/anencefalia1.htm>. Acesso em: 5 maio 2011.

${ }^{84}$ In: FERNANDES, Maíra Costa. Ob. Cit. p. 138.
} 
ela [referindo-se à filha que gerava] no caixão. Eu acordava gritando, soluçando. $\mathrm{O}$ meu marido tinha outro sonho. Ele sonhava que o bebê ia nascer com cabeça de monstro. Ele havia lido sobre anencefalia na internet. Se você vai buscar informações é aterrorizante. Ele sonhava que ela [novamente, referindo-se à filha] tinha cabeça de dinossauro. Quando chegou perto do nascimento, os sonhos pioraram. Eu queria ter tirado uma foto dela [da filha] ao nascer, mas os médicos não deixaram. Eu não quis velório. Deixei o bebê na funerária a noite inteira e no outro dia enterramos. Como não fizeram o teste do pezinho na maternidade, foi difícil conseguir o atestado de óbito para enterrar.

Relatos como esse evidenciam que a manutenção compulsória da gravidez de feto anencéfalo importa em graves danos à saúde psíquica da família toda e, sobretudo, da mulher. Enquanto, numa gestação normal, são nove meses de acompanhamento, minuto a minuto, de avanços, com a predominância do amor, em que a alteração estética é suplantada pela alegre expectativa do nascimento da criança; na gestação do feto anencéfalo, no mais das vezes, reinam sentimentos mórbidos, de dor, de angústia, de impotência, de tristeza, de luto, de desespero, dada a certeza do óbito.

Impedida de dar fim a tal sofrimento, a mulher pode desenvolver, nas palavras do dr. Talvane Marins de Moraes, representante da Associação Brasileira de Psiquiatria, ${ }^{85}$ "um quadro psiquiátrico grave de depressão, de transtorno, de estresse pós-traumático e até mesmo um quadro grave de tentativa de suicídio, já que não lhe permitem uma decisão, ela pode chegar à conclusão, na depressão, de autoextermínio" ${ }^{86}$

$\mathrm{Na}$ audiência pública, também foram reverberadas, entre outras, as vozes de três mulheres que, beneficiadas pela decisão liminar, optaram por antecipar o parto. São elas Érica, Camila e Michele, que expressaram, cada qual a sua maneira, a experiência vivida. Para Érica, continuar a gravidez "seria muito mais sofrimento. Minha barriga estaria crescendo, eu sentindo tudo e, no final, eu não ia tê-lo". ${ }^{87}$ Nas palavras de Camila, "o pior era olhar no espelho e ver aquela barriga, que não ia ter filho nenhum dela. Ela mexendo me perturbava muito. $\mathrm{O}$ meu maior medo era o de ter que levar mais quatro

\footnotetext{
${ }^{85}$ Ver nota de rodapé 81.

${ }^{86}$ Quarto dia de audiência pública (transcrição, folha 1.413).

${ }^{87}$ Depoimentos trazidos pela dra. Lia Zanotta Machado no terceiro dia de audiência (transcrição, folhas $1 \mathrm{~d} 299$ e $1 \mathrm{~d} 300)$.
} 
meses de gravidez, registrar, fazer certidão de óbito e enterrar horas depois de nascer" ${ }^{88}$ A antecipação do parto, disse Camila, "foi como se tirassem um peso muito grande das minhas costas; como se tivessem tirado com a mão o peso; parecia que eu estava carregando o mundo dentro de mim". ${ }^{89}$ Michele afirmou que, ao decidir interromper a gestação, nada mais fez do que "aquietar aquilo que estava se passando". .90

Pesquisa realizada no hospital da Universidade de São Paulo, no período de janeiro de 2001 a dezembro de 2003, com pacientes grávidas de fetos portadores de anomalia incompatível com a vida extrauterina, dá conta de que $60 \%$ das entrevistadas não só experimentaram sentimento negativo choque, angústia, tristeza, resignação, destruição de planos, revolta, medo, vergonha, inutilidade, incapacidade de ser mãe, indignação e insegurança como também diriam a outra mulher, em idêntica situação, para interromper a gestação. ${ }^{91}$

O sofrimento dessas mulheres pode ser tão grande que estudiosos do tema classificam como tortura o ato estatal de compelir a mulher a prosseguir na gravidez de feto anencéfalo. Assim o fizeram, nas audiências públicas, a dra. Jaqueline Pitanguy ${ }^{92}$ e o dr. Talvane Marins de Moraes. ${ }^{93}$ Nas palavras da dra. Jacqueline Pitanguy, "obrigar uma mulher a vivenciar essa experiência é uma forma de tortura a ela impingida e um desrespeito aos seus familiares, ao seu marido ou companheiro e aos outros filhos, se ela os tiver". Prosseguiu, "as consequências psicológicas de um trauma como esse são de longo prazo. Certamente a marcarão para sempre. Seu direito à saúde, entendido pela Organização Mundial de Saúde como o direito a um estado de bem-estar físico e mental, está sendo desrespeitado em um país em que a Constituição considera a saúde um direito de todos e um dever do Estado"..$^{44}$

Como bem destacam Telma Birchal e Lincoln Frias, embora:

\footnotetext{
${ }^{88}$ Folha 1.300.

${ }^{89}$ Folha 1.301.

${ }^{90}$ Folha 1.301.

${ }^{91}$ BENUTE, Gláucia Rosana Guerra; NOMURA, Roseli Mieko Yamamoto; LÚCIA, Mara Cristina Souza de; ZUGAUB, Marcelo. Interrupção da gestação após o diagnóstico de malformação fetal letal: aspectos emocionais. Revista Brasileira de Ginecologia e Obstetrícia, Rio de Janeiro, v. 28, n. 1, jan. 2006. Disponível em: <www.scielo.br $>$.

${ }_{92}^{92}$ Socióloga e cientista política, ex-professora de sociologia na Pontifícia Universidade Católica do Rio de Janeiro e na Rutgers University, Nova Jérsei, Estados Unidos, representante do Conselho Nacional dos Direitos da Mulher.

${ }^{93}$ Ver nota de rodapé 81.

${ }^{94}$ Terceiro dia de audiência pública, transcrição, folha 1.350.
} 
(...) no contexto, existam outras pessoas envolvidas, o sofrimento de ninguém é maior do que o da gestante, porque o feto anencéfalo é um acontecimento no corpo dela. A gestante, neste caso, nem mesmo chegará a ser mãe, pois não haverá - nem ao menos há - um filho. Ao obrigar a mulher a conservar um feto que vai morrer, ou que tecnicamente já está morto, o Estado e a sociedade se intrometem no direito que ela tem à integridade corporal e a tomar decisões sobre seu próprio corpo. No caso de fetos sadios, pode-se ainda discutir se a mulher é obrigada a ter o filho, pois ele será uma pessoa e, portanto, presume-se que tenha direito a ser preservado. Mas o feto anencéfalo nunca será uma pessoa, não terá uma vida humana, não é nem mesmo um sujeito de direitos em potencial (...). ${ }^{95}$

Consoante Zugaib, Tedesco e Quayle, "a ausência do objeto de amor parece tão irreparável que pode levar ao desejo de morrer, como maneira de reunir-se ao filho perdido. Tal dinâmica merece cuidados especiais, podendo levar a comportamentos impulsivos de autodestruição, especialmente se associada à depressão" ${ }^{96}$

Esse foi o entendimento endossado pelo Comitê de Direitos Humanos da Organização das Nações Unidas. ${ }^{97}$ Em decisão histórica, proferida em novembro de 2005, no "Caso K.L. contra Peru”, o Comitê assentou equiparar-se à tortura obrigar uma mulher a levar adiante a gestação de um feto anencéfalo. A paciente de 17 anos e a mãe dela, alertadas pelo ginecologista sobre os riscos advindos da mantença da gestação de um feto anencéfalo, concordaram em realizar o procedimento de interrupção terapêutica. Apesar de a lei penal peruana permitir o aborto terapêutico e atribuir pena de pequena gradação ao aborto sentimental ou eugênico, ${ }^{98}$ o diretor do hospital, dr. Maximiliano

\footnotetext{
${ }^{95}$ Ob. cit. p. 27.

${ }^{96}$ Apud MENDES, Thalita Bizerril Duleba. A interrupção seletiva de gestação de feto anencéfalo como conduta atípica. Universidade Federal do Paraná, 2007. p. 60.

${ }^{97}$ A dra. Eleonora Menecucci de Oliveira, ouvida no quarto dia de audiência pública, referiu-se ao precedente. Leiam: “Nosso país deveria observar o que vem acontecendo no plano internacional em relação, por exemplo, às respostas que os Comitês de Direitos Humanos das Nações Unidas vêm ofertando no plano global. Este Comitê, em duas oportunidades, já se manifestou sobre o assunto: em 1996, considerou que a possibilidade de um aborto gerar uma penalidade criminal representa uma forma de tratamento desumano em relações às mulheres; em 2005, considerou que a impossibilidade de interromper a gravidez, em caso de gestação de anencéfalo, foi causa de um grande sofrimento. Tratava-se do caso específico de Caelli, uma jovem peruana, que, aos 17 anos de idade, viu-se confrontada com uma gravidez de feto anencéfalo" (folha 1.380).

${ }^{98}$ Os artigos 119 e 120 do Código Penal peruano trazem as seguintes disposições:
} 
Cárdenas Diaz, recusou-se a firmar a autorização necessária para o ato cirúrgico, o que obrigou a paciente a dar à luz o feto. Como consequência, a gestante foi acometida de depressão profunda, com prejuízos à saúde mental e ao próprio desenvolvimento. Ao analisar o episódio, o Comitê de Direitos Humanos considerou cruel, inumano e degradante o tratamento dado a KL. Reputou violado também o direito dela à privacidade. ${ }^{99}$

Posteriormente, em dezembro de 2008, em entrevista concedida ao Center for Reproductive Rights, KL, então com 22 anos, residente em Madri, local onde estudava para formar-se em engenharia, descreveu ter-se sentido extremamente deprimida, solitária, confusa e culpada à época da gravidez e do nascimento do anencéfalo, que perdurou por apenas quatro dias. ${ }^{100}$ Indagada sobre como se sentia em relação à decisão do Comitê de Direitos Humanos, revelou estar feliz e disse que dificilmente quem não experimentou tal situação sabe o quão penosa e dolorosa ela é. ${ }^{101}$

Quando inexistiam recursos tecnológicos aptos a identificar a anencefalia durante a gestação, o choque com a notícia projetava-se para o momento do parto. Atualmente, todavia, podem-se verificar nove meses de angústia e sofrimento inimagináveis. Como ressaltei na decisão liminar, os avanços médicos e tecnológicos postos à disposição da humanidade devem servir não para inserção, no dia a dia, de sentimentos mórbidos, mas, justamente, para fazê-los cessar.

É possível objetar, tal qual o fez a dra. Elizabeth Kipman Cerqueira ${ }^{102}$ em audiência pública, o sentimento de culpa que poderá advir da decisão de

Art. 119 - Aborto terapêutico

Não é punível o aborto praticado por um médico com o consentimento da mulher grávida ou de seu representante legal, se o tiver, quando é o único meio para salvar a vida da gestante ou para evitar um mal grave e permanente em sua saúde.

Art. 120 - Aborto sentimental e eugênico

O aborto será reprimido com pena privativa de liberdade não maior que três meses:

1. Quando a gravidez seja consequência de violação sexual fora do matrimônio ou inseminação artificial não consentida e ocorrida fora do matrimônio, sempre que os fatos tiverem sido denunciados ou investigados, ao menos policialmente; ou

2. Quando é provável que o ser em formação leve a um nascimento com graves defeitos físicos ou psíquicos, sempre que exista diagnóstico médico. (Tradução livre. Cópia eletrônica do referido diploma legal encontra-se disponível em: <www.devida.gob.pe/documentacion/Decreto\%20 Legislativo\%20635-CODIGO\%20PENAL.doc>. Acesso em: 6 maio 2011.)

$99 \mathrm{O}$ pronunciamento completo do Comitê de Direitos Humanos da Organização das Nações Unidas está disponível em: <ww.cladem.org-espanol-regionales-litigio_internacionalCAS5Dictament\%20KL.asp>. Acesso em: 8 jun. 2010.

${ }^{100}$ Disponível em: <http://reproductiverights.org>. Acesso em: 8 jun. 2010.

${ }^{101}$ Disponível em: <http://reproductiverights.org >. Acesso em: 8 jun. 2010.

${ }^{102}$ Ver nota de rodapé 78 . 
antecipar o parto. Na mesma linha, em memorial, a Conferência Nacional dos Bispos do Brasil defendeu que o gesto não reduz a dor. Em resposta a essas objeções, vale ressaltar caber à mulher, e não ao Estado, sopesar valores e sentimentos de ordem estritamente privada, para deliberar pela interrupção, ou não, da gravidez. Cumpre à mulher, em seu íntimo, no espaço que lhe é reservado - no exercício do direito à privacidade - , sem temor de reprimenda, voltar-se para si mesma, refletir sobre as próprias concepções e avaliar se quer, ou não, levar a gestação adiante.

Ao Estado não é dado intrometer-se. Ao Estado compete apenas se desincumbir do dever de informar e prestar apoio médico e psicológico à paciente, antes e depois da decisão, seja ela qual for, o que se mostra viável, conforme esclareceu a então ministra da Secretaria Especial de Políticas para as Mulheres, Nilcéa Freire. ${ }^{103}$ Consignou Sua Excelência que:

(...) os serviços existentes para a interrupção voluntária da gravidez, para o abortamento legal, dispõem de equipes multidisciplinares aptas a fazerem esse acompanhamento [referia-se ao psicológico]. (...) Eu diria que, hoje, todos os serviços universitários existentes no país têm equipes multidisciplinares - e posso dizer isso, com certeza - , com acompanhamento de psicólogos, que permitirão informação e assistência às mulheres no tocante à sua decisão, seja pela continuidade da gestação, seja pela interrupção da gestação. ${ }^{104}$

Não se trata de impor a antecipação do parto do feto anencéfalo. De modo algum. O que a arguente pretende é que "se assegure a cada mulher o direito de viver as suas escolhas, os seus valores, as suas crenças" ${ }^{105}$ Está em jogo o direito da mulher de autodeterminar-se, de escolher, de agir de acordo com a própria vontade num caso de absoluta inviabilidade de vida extrauterina. Estão em jogo, em última análise, a privacidade, a autonomia e a dignidade humana dessas mulheres. Hão de ser respeitadas tanto as que optem por prosseguir com a gravidez - por sentirem-se mais felizes assim ou por qualquer outro motivo que não nos cumpre perquirir - quanto as que prefiram interromper a gravidez, para pôr fim ou, ao menos, minimizar

\footnotetext{
${ }^{103}$ Graduada em Medicina pela Universidade do Estado do Rio de Janeiro, ex-professora e exreitora desta instituição.

${ }^{104}$ Quarto dia de audiência pública, 16 de setembro de 2008 (transcrição, folhas 1.397 e 1.398).

${ }^{105}$ Quarto dia de audiência pública (transcrição, folha 1.421).
} 
um estado de sofrimento. Conforme bem enfatizado pelo dr. Mário Ghisi, representante do Ministério Público na audiência pública, "é constrangedora a ideia de outrem decidir por mim, no extremo do meu sofrimento, por valores que não adoto. É constrangedor para os direitos humanos que o Estado se imiscua no âmago da intimidade do lar para decretar-lhe condutas que torturam". ${ }^{106}$

Alberto Silva Franco chama a atenção para outro aspecto a ser considerado caso se obrigue a mulher a levar a gravidez a termo. Afirma: "se ocorrer o nascimento do anencéfalo, 'não receberá ele nenhuma manobra médica de reanimação, nem nenhum procedimento de suporte vital, em virtude da inocuidade de qualquer medida'. (...) Nada realmente justifica o emprego de recursos tecnológicos para tornar viável o que não dispõe congenitamente de viabilidade". Continua: "o argumento de que todos nascemos para morrer e que, por isso, o feto anencéfalo não destoa da regra geral, está longe de ser um argumento válido. Trata-se, na realidade, de um truísmo dispensável" ${ }^{107}$ Digo então, senhor presidente, que não se pode exigir da mulher aquilo que o Estado não vai fornecer, por meio de manobras médicas.

Franquear a decisão à mulher é medida necessária ante o texto da Convenção Interamericana para Prevenir, Punir e Erradicar a Violência contra a Mulher, também conhecida como "Convenção de Belém do Pará", ratificada pelo Estado brasileiro em 27 de novembro de 1995, cujo artigo $4^{\circ}$ inclui como direitos humanos das mulheres o direito à integridade física, mental e moral, à liberdade, à dignidade e a não ser submetida a tortura. Define como violência qualquer ato ou conduta baseada no gênero, que cause morte, dano ou sofrimento físico, sexual ou psicológico à mulher, tanto na esfera pública como na esfera privada. ${ }^{108}$

Não se coaduna com o princípio da proporcionalidade proteger apenas um dos seres da relação, privilegiar aquele que, no caso da anencefalia, não tem sequer expectativa de vida extrauterina, aniquilando, em contrapartida, os direitos da mulher, impingindo-lhe sacrifício desarrazoado. A imposição estatal da manutenção de gravidez cujo resultado final será irremediavelmente a morte do feto vai de encontro aos princípios basilares do sistema constitucional, mais precisamente à dignidade da pessoa humana, à liberdade,

\footnotetext{
${ }^{106}$ Último dia de audiência pública (transcrição, folha 77).

${ }^{107}$ Ob. cit. p. 409.

${ }^{108} \mathrm{O}$ texto completo da Convenção encontra-se disponível em: <www.cidh.oas.org >. Acesso em: 11 jan. 2011.
} 
à autodeterminação, à saúde, ao direito de privacidade, ao reconhecimento pleno dos direitos sexuais e reprodutivos de milhares de mulheres. $\mathrm{O}$ ato de obrigar a mulher a manter a gestação, colocando-a em uma espécie de cárcere privado em seu próprio corpo, desprovida do mínimo essencial de autodeterminação e liberdade, assemelha-se à tortura ${ }^{109}$ ou a um sacrifício que não pode ser pedido a qualquer pessoa ou dela exigido.

A integridade que se busca alcançar com a antecipação terapêutica de uma gestação fadada ao fracasso é plena. Não cabe impor às mulheres o sentimento de meras "incubadoras" ou, pior, "caixões ambulantes", na expressão de Débora Diniz. ${ }^{110}$

Simone de Beauvoir já exclamava ser o mais escandaloso dos escândalos aquele a que nos habituamos. Sem dúvida. Mostra-se inadmissível fechar os olhos e o coração ao que vivenciado diuturnamente por essas mulheres, seus companheiros e suas famílias. Compete ao Supremo assegurar o exercício pleno da liberdade de escolha situada na esfera privada, em resguardo à vida e à saúde total da gestante, de forma a aliviá-la de sofrimento maior, porque evitável e infrutífero.

Se alguns setores da sociedade reputam moralmente reprovável a antecipação terapêutica da gravidez de fetos anencéfalos, relembro-lhes de que essa crença não pode conduzir à incriminação de eventual conduta das mulheres que optarem em não levar a gravidez a termo. O Estado brasileiro é laico e ações de cunho meramente imorais não merecem a glosa do direito penal.

A incolumidade física do feto anencéfalo, que, se sobreviver ao parto, o será por poucas horas ou dias, não pode ser preservada a qualquer custo, em detrimento dos direitos básicos da mulher. No caso, ainda que se conceba o direito à vida do feto anencéfalo - o que, na minha óptica, é inadmissível, consoante enfatizado - , tal direito cederia, em juízo de ponderação, em prol dos direitos à dignidade da pessoa humana, à liberdade no campo sexual, à autonomia, à privacidade, à integridade física, psicológica e moral e à saúde,

\footnotetext{
${ }^{109} \mathrm{O}$ artigo $1^{\circ}$ da Constituição Federal define como um dos fundamentos do estado democrático de direito a dignidade da pessoa humana e o artigo 5o, inciso III, dispõe que ninguém será submetido a tortura nem a tratamento desumano ou degradante.

A Lei $n^{\circ} 9.455 / 97$, no artigo 1丷, prevê:

Constitui crime de tortura:

I - constranger alguém com emprego de violência ou grave ameaça, causando-lhe sofrimento físico ou mental (...);

c) em razão de discriminação racial ou religiosa.

${ }^{110}$ Ver nota de rodapé 63.
} 
previstos, respectivamente, nos artigos $1^{\circ}$, inciso III, 5ํ, cabeça e incisos II, III e X, e 6oㅡ, cabeça, da Carta da República.

Os tempos atuais, realço, requerem empatia, aceitação, humanidade e solidariedade para com essas mulheres. Pelo que ouvimos ou lemos nos depoimentos prestados na audiência pública, somente aquela que vive tamanha situação de angústia é capaz de mensurar o sofrimento a que se submete. Atuar com sapiência e justiça, calcados na Constituição da República e desprovidos de qualquer dogma ou paradigma moral e religioso, obriga-nos a garantir, sim, o direito da mulher de manifestar-se livremente, sem o temor de tornar-se ré em eventual ação por crime de aborto.

Ante o exposto, julgo procedente o pedido formulado na inicial, para declarar a inconstitucionalidade da interpretação segundo a qual a interrupção da gravidez de feto anencéfalo é conduta tipificada nos artigos 124, 126, 128, incisos I e II, do Código Penal brasileiro. 